\title{
The Left and Universal Basic Income: The role of ideology in individual support
}

\author{
Hanna Schwander and Tim Vlandas tim.vlandas@ox.ac.uk \\ Journal of International and Comparative Social - pre-proof accepted September 2020
}

\begin{abstract}
Few studies analyse individual support for Universal Basic Income (UBI). This article theorises and explores empirically the relationship between different strands of left ideology and support for UBI across European countries. We delineate three types of concerns about capitalism: 'Labourist Left' worry about exploitation; 'Libertarian Left' about repression; and 'Social Investment Left' about inefficiencies. Contrary to expectations, our results based on data from the European Social Survey suggest that having high concerns about exploitation is positively correlated with support for UBI, whereas repression concerns are negatively correlated with support. In line with our hypothesis, left-leaning individuals with efficiency concerns are more likely to support UBI. Our findings call for more detailed surveys and further research on the different ideologies within the Left and how these relate to variation in support for UBI which would shed further light on the resulting potential coalition dynamics for a larger-scale introduction of UBI.
\end{abstract}

Keywords: universal basic income, partisanship, Europe, ideology, political Left, welfare state, preferences

\section{Introduction}

Traditionally, the introduction and design of welfare policies has been explained with reference to power relations, institutions, and structural factors, but recent contributions forcefully argue that micro-level preferences matter for explaining both politics and policies (e.g. Hacker et al., 2013; Cusack et al., 2006). Consequently, the political economy and comparative social policy literatures have increasingly paid attention to individual-level support for welfare state policies, and our understanding of material and value-driven support for social policies has significantly improved in the last decades (Schwander, 2019;

Häusermann et al., 2016; Rehm, 2011; Iversen and Soskice, 2001). 
By contrast, the study of UBI has focused on the normative and economic desirability of such a scheme, not least because a UBI has not so far been introduced on a national scale. Instead, this article seeks to contribute to our understanding of the drivers of individual support for UBI, which should be of interest to scholars of political economy and comparative social policy. Indeed, given its different entitlement structure than traditional social benefits and the fact that a UBI at the national level does not yet exist, we do not know whether the usual factors ${ }^{1}$ driving individual support for a UBI are relevant in this case. As Vlandas (2020) argues in a recent contribution, UBI can therefore be considered a 'hard case' for existing political economy and welfare state expectations about variation in individual preferences for social policies.

Our focus is part of a growing scholarly interest in explaining variation in individual attitudes towards UBI (e.g. Roosma and van Oorschot, 2018; Lee, 2018; Chrisp and Martinelli, 2018; Vlandas, 2020). These studies represent a crucial addition to the more normative and economic literature that have so far dominated studies of UBI (see Van Parijs and Vanderborght, 2017). Existing empirical analyses suggest that support for UBI is particularly high among individuals in economically vulnerable situations (low income, precarious employment) and among individuals that support the welfare state in general (Roosma and van Oorschot, 2020; Parolin and Siöland, 2020; Vlandas, 2020). Hence, in line with the broader literature on social policy preferences, material self-interest and ideology seem to be crucial drivers for this new policy vision too.

In this article, we add to this recent literature by focusing on the role of left ideology and its association with different patterns of left-wing individual support for UBI. We

\footnotetext{
${ }^{1}$ For example, material self-interest and political ideology. For recent overviews on the drivers of social policy preferences that discuss the distinction between self-interest and ideology, see Garritzmann et al. (2018); Bremer and Schwander (2019); Häusermann et al. (2015); Hacker et al. (2013); and Margalit (2013).
} 
consider looking at the role of ideology in shaping support among the Left worthwhile for two reasons. First, without the support of the Left, it is unlikely that any governments can successfully implement UBI. Here, the relevance of public opinion is particularly pertinent: Much of UBI's intellectual origins come from the Left and the scheme finds most but not all of its support among left-wing citizens; yet parts of the union movement are often sceptical of UBI (Van Parijs and Vanderborght, 2017). Hence, our findings are relevant to those interested in the political conditions to enable an implementation of UBI, both practically as well as the academic welfare state literature.

A second reason relates to the large literature underscores the importance of ideology for welfare state preferences (Linos and West, 2003; Dimick et al., 2018; Jæger, 2006; Bremer and Schwander, 2019). While valuable, previous literature has not systematically investigated the relevance of ideology for the case of UBI. Yet, ideology might a priori be especially relevant for the UBI as the scheme attracts not only support from both the political Left and Right but has also historically divided the Left (see also Chrisp and Martinelli (2019) and the contributions in Van Parijs (2018a)).

In sum, disentangling and explaining variation in support for UBI within the Left is the contribution of the article. We explore the question of variation in left-wing support for the UBI by focusing on the nature of the Left's criticism about capitalism. Wanting to change capitalism is the defining difference between the political Left and Right. We posit that the reasons why the Left wishes to change capitalism shape its attitudes towards UBI. To do so, we conceptualise three strands of left ideology: Labourist, Libertarian and Social Investment. The Labourist Left's primary criticism of capitalism focuses on its exploitative nature and it wishes to redress this issue primarily through collective action and redistribution. The Libertarian Left's main issue is instead the repression of labour and its 'unfreedom' in a 
capitalist system and it sees labour's decommodification as the solution. The Social Investment Left emphasises that laissez-faire capitalism might be inefficient as it is prone to market failures so that intelligently designed welfare institutions can overcome these market failures to the benefit of the individual citizen. Building on insights from political theory literature on UBI, we hypothesise that the Libertarian Left is most favourable towards UBI because a UBI would decommodify citizens and therefore maximize individual freedom. By contrast, the Labourist Left should be sceptical towards UBI because it changes nothing to the underlying exploitative nature of capitalism. Drawing on the welfare state literature, we expect those who are favourable to social investment to support UBI.

After a brief review of the existing political economy literature on support for UBI in the next section, we develop our hypotheses about how different concerns with capitalism results in varying support for UBI within the Left. We then present and discuss our results in the empirical section: logistic regressions indicate that support for UBI does indeed vary within left-wing citizens. Consistent with expectations from the welfare state literature, leftwing respondents with efficiency concerns about the market are more supportive of UBI. However, and contrary to expectations from political theory literature on UBI, our results suggest that being concerned about the exploitation of labour is positively correlated with support for UBI, whereas repression concerns are negatively correlated with support.

\section{Theoretical framework}

The basic income and the three strands of left ideology

In this article, we focus on variation in support for the basic income among politically left-leaning individuals. While UBI are generally more popular among left-leaning citizens (Parolin and Siöland, 2020; Vlandas, 2020; Lee, 2018), the reluctance of trade unionists to embrace UBI is prima facie puzzling and the heated debate about the merits and dangers of 
an UBI within the Left calls for further investigation (see for instance the contributions in Van Parijs 2018). We start by defining what we mean by the political Left. Notwithstanding many ideological differences within the Left (see Przeworski and Sprague, 1986; Kitschelt, 1994; March, 2011), left ideologies united around the goal of achieving social justice. The Left emphasises equality of outcomes and opportunity, and favour state intervention to achieve these goals. Hence, on the equality-freedom dimension, they side with equality, which goes along with scepticism about laissez-faire capitalism (Rothstein, 2018; Giddens, 1998). Another left criticism concerns the constraining effect of capitalist societies on individual autonomy (Kitschelt, 1988). The notion of social justice therefore goes beyond material equality but encompasses the positive individual freedom to live the life one chooses. $^{2}$

Our argument focuses on the most important source of criticism against laissez-faire capitalism voiced by different left ideologies. Our starting point is van Parijs' (2018c: 2) differentiation between the Labourist and the Libertarian Left. Building on the welfare state literature, we add a newer third strand of left ideology, the Social Investment Left (Giddens, 1998; Jenson, 2012; Hemerijck, 2018) because it is analytically distinct from both Labourist and Libertarian Left.

\section{Labourist Left}

The Labourist Left's main criticism of capitalism is the exploitation of labour by capitalists, who appropriate parts of the profit that should rightfully belong to workers. As Werner

\footnotetext{
${ }^{2}$ Within this broad church of Left ideologies, we focus on 'democratic revisionists', that is Left movements that adhere to the primacy of politics over economy and believe that a democratic state could bring about critical transformations in the existing order (Berman, 2009).
} 
Sombart notes, Labourists glorify the value of work (cited in Van Parijs and Vanderborght, 2017: 193). In this view, the main solution to address the 'moral entitlement' of workers to the fruits of their commodification is a massive redistribution of national income and wealth. This is also the main reason why Labourists remain reluctant to support UBI. Rather than 'the right to income', they prioritise the 'right to work' (Van Parijs, 2018b). As UBI appears as a threat to the right to work (Steinvorth, 2000; Michel, 2000) it also threatens individual recognition (Michel, 2000; Krebs, 2000), merely compensating social and economic exclusion (Anderson, 2000; Hassel, 2016) instead of addressing its root cause.

Labourists also contest that UBI would reduce unemployment (Steinvorth, 2000), poverty or income inequality (Navarro, 2018). Historically, Labourists argue that there has never been a close link between technological progress, productivity and the demand of labour questioning the necessity of a basic income. (Navarro, 2018). Rather, they identify political factors, specifically capital-labour relations, as the main channel through which productivity gains translate into additional available jobs and call for continuing the organised political struggle for better work conditions, fair remuneration and effective fiscal and redistributive policies to fight inequality and poverty (Navarro, 2018).

Moreover, UBI could quickly assume the function of a subsidy to low-paid work or an open door to 'mini-jobs' (Mestrum, 2018: 24), a concern Labourists have voiced in the past with respect to in-work and minimum income benefits as well (Vlandas, 2013). UBI might also challenge established combination of work-related programs and income transfers related to specific conditions.

Finally, Labourists also have strategic reasons to oppose a scheme unrelated to employment. Social democratic parties and trade unions, which often follow a Labourist logic, have strong stakes in the social insurance systems that from the bulk of most of today's 
welfare states. They were not only the initiators of such schemes but are still closely involved in the management of these schemes (Van Parijs, 2018b).

\section{Left Libertarians}

In contrast to Labourist Left, Left Libertarians focus less on the exploitation of labour but are concerned with freedom as a requirement for a just society (Van Parijs, 1995; Powell, 2012). In this perspective, capitalism is therefore seen as a repressive system that forces individuals to commodify themselves on the labour market. To quote Van Parijs' (2017: 1): "many, despite being formally free, have no other real option than to sell their labour power to the owners of capital".

The first step in Van Parijs' argument posits that the promotion of real freedom is a requirement for real justice. In a free society individuals ought not only to have the rights connected with self-ownership ('formal freedom'), but in addition "each person [should have] the greatest possible opportunity to do whatever she might want to do" (Van Parijs, 1995: 25). At the core of libertarianism is the view that all adult members of a society have the absolute right to dispose as they wish of their own persons and of the goods they have legitimately acquired (Van Parijs and Vanderborght, 2017: : 119). In the question of how natural resources (as the source of all goods) can be legitimately appropriated lies the differences between Right and Left Libertarians: the first invoke a "first come, first served" principle, while the Libertarian Left believes that all natural resources are ultimately distributed equally between mankind (Van Parijs and Vanderborght, 2017: : 120). Crucially, Left Libertarians such as van Parijs consider access to good jobs as such a natural resource for which compensation has to be paid. In affluent societies with involuntary unemployment and 'job envy', good jobs undoubtedly represent attractive resources because they provide 
additional income, social standing, job satisfaction, and so on. In turn, in these societies the payment of the highest possible share of unearned external resources due to each equally entitled person would result in a substantial UBI.

The introduction of a significant UBI would clearly boost the real freedom of those with the least options. For instance, they would then be in a position to pursue education, child caring, surfing, writing, etc, without fear of starvation. They would also be free to engage in paid work even at a low wage work without worrying that they will earn their way out of their basic income (Van Parijs, 1995: 35-38). Today and even more so in times of a global pandemic, this argument has become more compelling: the possibility of a 'future without work' justifies the need to substitute work with a basic income because there will simply not be sufficient work (Navarro, 2018).

Moreover, a basic income would force employers to create more acceptable and less demeaning types of work because no one would be compelled to work. The elimination of routine forms of employment, which provide little enrichment, needing little intellectual or creative input, is highly desirable for Left Libertarians. Individuals should be enabled to be (re)educated and (re)trained for more socially useful activities in caring services or more challenging and fulfilling tasks (cf. Zwolinski (2013)). A basic income frees individuals from being subjected to humiliating and/or demeaning income or means testing procedures by public officials. From current discussions on old age poverty in Germany, we know for instance that up to a third of those entitled to supplementary benefits do not take them, partly because they do not know about their existence, but also because they resent the humiliating means-testing process (Sueddeutsche Zeitung, 20 ${ }^{\text {th }}$ September 2019).

From a feminist perspective, UBI liberates women from their dependence of the male breadwinner (Chrisp and Martinelli, 2019) and contributes to a more equal sharing of 
domestic responsibilities (Wilson, 2018: 62). ${ }^{3}$ This speaks to the repression concerns that

Left Libertarians voice against laissez-faire capitalism and centralized bureaucracies that go beyond material equality. Socially progressive movements such as the women's movement or the LTBG movement were historically closely linked with Left Libertarians (Kitschelt, 1988).

\section{Social Investment Left}

The main argument of the Social Investment Left ${ }^{4}$ for state intervention in capitalism is that the latter is prone to market failures, for instance stemming from externalities, public goods, incomplete contracting, and information problems of various kinds (Keman, 2011; Giddens, 1998; Vandenbroucke, 2001). A pure market logic therefore does not incentivise sufficient long-term investments that yield to personal development and economic growth. The following examples illustrate this argument: although post-industrial economies need skilled and trained workforces, citizens will not always invest in - or even maintain - their human capital, but instead often choose to forego training in favour of short-term income if they fear about making ends meet. Another example concerns imperfect capital markets, which prevent individuals from borrowing the individually and socially optimal amount for investments in human capital. Fear of losing basic security also results in short-term and short-sighted

\footnotetext{
${ }^{3}$ For a feminist critique of the basic income, see Krebs (2000).

${ }^{4}$ There has been debates whether the social investment paradigm truly is a left project as it embraces a market logic and accepts outcome inequality. We argue it is. Indeed, social investment is concerned with the promotion of equal opportunity, independent of socio-economic class, gender or ethnicity and "Increase social inclusion and minimise the intergenerational transfer of poverty as well as to ensure that the population is well-prepared for the likely employment conditions (less job security; more precarious forms of contracts) of contemporary economies" (Jenson 2012: 61). These are genuine left concerns. Social Investment is also left in its methods to achieve these goals: social investment advocates call for the state to foster these goals (goals (Jenson, 2012; Hemerijck, 2018; Esping-Andersen, 2002) which is again distinctly left. The argument that social investment is a left project is also supported empirically: At the macro-level, social investment spending is found to be higher in countries with a traditional of strong left parties (Bonoli, 2013; Huber and Stephens, 2006). At the level of individual support, left-leaning individuals are more likely to support social investment (Garritzmann et al., 2018). Bremer and Schwander (2019) however point to variation of left support for social investment.
} 
behaviours, whereas individuals with income security can develop long-term and, therefore more stable, strategies. Indeed, "[t]here is more than money at stake in the poverty trap. The income poverty trap is also a security trap" (Haagh, 2018: 82). Equally, insufficient child care provisions might prevent adequate investments in young children's cognitive developments early in life with long-term adverse effects, in particular regarding the intergenerational transmission of poverty and disadvantages (Hemerijck, 2017; Jenson, 2012).

What all these examples have in common characterising the Social Investment Left ideology is the idea that the state could increase efficiency of markets through well-designed interventions (Giddens, 1998). Instead of promoting aggregate demand for labour, for instance via state investments to increase public or private consumption, such policies aim to increase workers' employability by investing in their skills or increasing incentives to take up work, and/or to break the intergenerational cycle of disadvantages (Jenson, 2012; Hemerijck, 2018).

The basic income creates an income floor which helps to motivate long-term investment strategies. UBI can for instance motivate a person to return to education and support long-term labour market integration. In line with the social investment ideology, a basic income therefore has a preventive and active function, in particular as it does not reduce employment incentives but might motivate individuals to look for 'better work'. In a life course perspective, social investment policies have the function to enable individuals to prevent and overcome difficult life events and life transitions without losing their capacity to support themselves economically (Kvist, 2017). UBI will fulfil precisely this function. The basic income is part of a systemic change of social rights in relation to welfare and work incentivizing individuals in a sustainable, long-term and preventive manner and helps to create, strengthen, maintain, re-establish, and use individuals' capabilities and skills (see Garritzmann et al., forthcoming: 6). We therefore expect that the Social Investment Left 
would support a basic income as it allows individuals to develop long-term personal strategies. ${ }^{5}$ Table 1 summarises our expectations concerning the ranking of support for UBI within the Left.

< Table 1 about here >

\section{Data, methods and results}

To test our expectations, we rely on the $8^{\text {th }}$ wave of the European Social Survey (ESS) which includes the following question about support for UBI:

\footnotetext{
"Some countries are currently talking about introducing a basic income scheme. Are you against or in favour of this scheme? A basic income scheme includes all of the following: (1) The government pays everyone a monthly income to cover essential living costs; (2) It replaces many other social benefits; (3) The purpose is to guarantee everyone a minimum standard of living; (4) Everyone receives the same amount regardless of whether or not they are working; (5) People also keep the money they earn from work or other sources; (6) This scheme is paid for by taxes."
}

Our dependent variable measures support for UBI by coding it 1 if respondents choose 'in favour' or 'strongly in favour' of the scheme, and 0 otherwise. We use the left-right selfplacement 11-points scale of the ESS to identify left-wing citizens by creating a dichotomous variable: $0-4$ on the left-right scale is coded 1 to capture the Left, while other values are coded 0. Using this variable, we restrict our sample to left-wing respondents. The ESS does

\footnotetext{
${ }^{5}$ Note that the Social Investment Left is therefore not equivalent to the Third Way ideology, which entails other types of efficiency concerns that also apply to the state and the presumed inefficiencies some of its policies are seen to entail. In this latter view, the solution is often seen to be a form of activation which can easily turn coercive and negative, granting benefits only conditional on proving 'willingness to work' (see: Bonoli (2013); Clasen and Clegg (2012); Eichhorst et al. (2008) Since activation rests on the principle that everyone is able and forced to work once his or her employability improves, it is arguable whether this is still a left-wing ideology and it could be expected that those with activation views are very critical towards an unconditional basic income. In fact, questions from the ESS about forcing unemployed people to work and sanctioning their refusal to do so are indeed negatively correlated with support for UBI (see section A3.2 in appendix).
} 
not include specific questions on concerns about capitalism, but it does include questions that allow us to create proxies of these concerns. Specifically, following from our theoretical framework distinguishing three types of concerns about capitalism, we identify a number of questions on attitudes towards redistribution, inequality, freedom, and social investment to map out the different dimensions in the attitudes that left-wing individuals display in their criticisms of capitalism:

- $\quad$ Pro-redistribution. We rename the ESS variable gincdif 'pro-redistribution' because it captures whether respondents think that governments should reduce differences in income levels.

- $\quad$ Pro-equality. Our second ESS variable is $s m d f s l v$, which we rename 'pro-equality', asks whether for "a fair society differences in standard of living should be small".

- Equal opportunity and being free. The third and fourth variables ask respondents about whether it is important (a) that "people are treated equally and have equal opportunities" and (b) "to make own decisions and be free".

- $\quad$ Pro-LGBT. The fifth variable aims to capture cultural liberalism by the respondents' agreement to the statement "Gays and lesbians free to live life as they wish".

- $\quad$ Pro-childcare and pro-parents. The sixth and seventh variables are based on two questions in concerning childcare and work-life balance, both of which have been shown to be key to the social investment paradigm (Nolan, 2013; Morel et al, 2012; Ansell and Gingrich, 2015; Hemerijck, 2017). Respondents choose value from (1) to (4) about the preferred degree of government responsibility. We call this variable 'pro-childcare'. The second variable is about whether there should be benefits for parents to combine work and family even if it means higher taxes. We call this variable 'pro-parents'. 
- $\quad$ Pro-unemployed education. Our eighth variable asks respondents whether they would spend more on education for unemployed at the cost of unemployment benefits.

All variables are coded in a way that higher values mean stronger agreement. We run a factor analysis which inductively extracts factors from these different variables thereby allowing us to identify latent ideology dimensions within the Left. The factor analysis on these eight variables identifies three different factors (indicated by the three factors with eigenvalues above 1 in table 2) which we associate with different left-wing ideologies.

Factor 1 loads positively on being favourable to redistribution, equality (of outcomes and opportunities), to a lesser extent on childcare, and the least on being favourable to provide more education to the unemployed at the expense of unemployment benefits. We call this factor the exploitation factor, which speaks to the concerns of the Labourists Left, since it captures people with concerns about the exploitative aspects of capitalism.

By contrast, factor 2 loads most positively on opportunities, freedom and supporting LGBT rights, as well as providing education instead of benefits to unemployed, but negatively on redistribution and equality. We call this the repression factor, which speaks to the concerns of Libertarian Left, since it captures people with concerns about the repressive nature of capitalism.

Finally, factor 3 attaches greater weight to childcare, benefits for parent and education for the unemployed at the cost of benefits, but negatively on freedom, pro-LGBT and equal opportunity. There is also a weak negative loading with redistribution and equality. This captures pro-social investment attitudes. We call this the efficiency factor, which speaks to the concerns of the Social Investment Left. We provide summary statistics in section A1.1 in appendix.

All our models include a standard set of control variables (Lee, 2018; Roosma and van Oorschot, 2018; Chrisp and Martinelli, 2018): gender, age, education, income, source of 
income and occupations ${ }^{6}$. As our dependent variable is binary, we use logistic regressions but the results are robust to alternative estimation methods, see section A3.4 in Appendix. Since respondents are clustered in countries and there might be unobservable heterogeneity across countries, we include country-fixed effects and rely on robust errors clustered by country.

All controls in our analysis below are included but not shown (see figure A2.2 in appendix for full results): male respondents are surprisingly more supportive, while lowincome respondents, especially in elementary occupations, are more supportive of UBI. Age and being on a temporary work contract are not statistically significant and this is also the case for most occupational identifiers. Finally, education has a positive and statistically significant coefficient, while most variables capturing sources of income are not statistically significant, except for the 'other benefits' variable (see table A2.3 in appendix).

Figure 1 reports the results for four different models. The first model pertains only to exploitation concerns, the second only to repression concerns, the third only to efficiency concerns, while the fourth model includes the three types of concerns together. For each model, we report the point estimate of the semi-standardised coefficients, which indicates the effect of one standard deviation change in the independent variable on the log odds of the dependent variable. Around each point estimate, we report the $95 \%$ as well as the $90 \%$ confidence intervals. When these confidence intervals overlap with the vertical zero line, then the variable under consideration has no statistically significant association with support for UBI.

The first model suggests that exploitation concerns among left-wing respondents have a positive and statistically significant association with support for UBI. The magnitude of the

\footnotetext{
${ }^{6}$ We follow the International Standard Classification Of Occupations: 1 Managers; 2 Professionals; 3 Technicians and Associate Professionals; 4 Clerical Support Workers 5 Services and Sales Workers; 6 Skilled Agricultural, Forestry and Fishery Workers; 7 Craft and Related Trades Workers; 8 Plant and Machine Operators and Assemblers; 9 Elementary Occupations. For more information, see https://www.ilo.org/public/english/bureau/stat/isco/isco08/index.htm
} 
effect is large in relation to other determinants of UBI support. This finding is at odds with the expectations of political theory work on UBI which we discussed in the theoretical section (see van Parijs, 2018b). Recall that exploitation concerns load strongly on proequality and pro-redistribution preferences, which suggest that respondents with these characteristics are more supportive of UBI and hence see this scheme as achieving these aims. This suggests that - unlike many proponents of traditional institutions of the welfare state, which tend to see these institutions as the best protection against exploitation and UBI as representing a minimalist safety net, left-wing individuals who care strongly about equality and exploitation tend to favour a UBI. ${ }^{7}$

We suspect that this can be explained - paradoxically - by the universal character of the UBI: Given that a UBI would be paid to everyone, it achieves a very high level of decommodification, which has been argued by power resource theorists to be necessary to reduce capitalist exploitation of labour (Korpi 2006). In a context where many social policies have been retrenched, made more conditional and recommodified (Knotz 2018; Knotz and Lindvall 2015), the UBI's universalist and fully de-commodifying characteristics might be especially appealing. Indeed, Roosma and van Oorschot's (2020) finding that support for targeting benefits to the poor and support for UBI are related hints in the same direction.

The second model shows that repression concerns are negatively associated with support for UBI. The effect is statistically significant at the 95\% level and - again - at odds with the expectations of the political theory literature on UBI. Recall that the repression concerns, characteristic of the Libertarian Left, load strongly on equal opportunity, being free, and cultural liberalism, but negatively on pro-redistribution and pro-equality. Given that redistribution preferences are often used as a proxy for general welfare state support, one

\footnotetext{
${ }^{7}$ In a recent study, Roosma and van Oorschot (2020) confirm the positive correlation between support for redistribution and UBI regardless of ideological orientation.
} 
might therefore speculate whether the two dimensions could also be interpreted as measuring a general pro-welfare state preference dimension, which loads positively with support for UBI (Vlandas, 2020; Parolin and Siöland, 2020; Roosma and van Oorschot, 2020). This result suggests that those who favour equality of opportunities, equal rights for LGBT, and freedom of action are largely opposed to the UBI.

This counter-intuitive finding could be because equality of opportunity is not understood as necessitating state intervention or instead because libertarians' dislike of the state interventionism is stronger than their desire for equal opportunities. Note that while this is true within the left, repression concerns are not negatively associated with UBI support once we extend our sample to the wider population to include both left and right leaning respondents (indeed Figure A4.6.1 in appendix clearly show that the coefficient is no longer statistically significant). Thus, repression concerns are not per se associated with lower support for UBI; only left-wing respondents who have particularly high repression concerns seem less likely to support it than other left-wing respondents ${ }^{8}$.

The third model shows a significantly positive correlation between efficiency concerns and support for UBI. This suggests that in line with our expectation, the Social Investment Left is indeed positively related to UBI. In this view, the UBI is seen as the ideal way of promoting individuals' ability to invest in their human capital. Roosma and van Oorschot (2020), whose study also finds a positive relationship between support for social investment and UBI, suggest that a UBI is perceived as a modern, innovative idea as an alternative for the current welfare state, just as Social Investment has been found to in other welfare state studies. The weak negative loading of this factor with pro redistribution and equality attitudes reveals that it is possible for left-wing individuals to support UBI even if

\footnotetext{
${ }^{8}$ We are grateful to a reviewer for pointing us in this direction.
} 
they do not care most strongly about egalitarianism. Note that this association holds when extending the sample to include all respondents, including both left and right leaning individuals (Figure A4.6.1 in appendix).

$<$ Table 2 about here>

$<$ Figure 1 about here >

Finally, if we include all three types of concerns in the same model, the effects also remain the same. Note further that these three types of concerns have the same effect when included on their own without any controls and they have strong predictive power. Indeed, when running a logistic regression only with the three independent variables capturing leftwing tradition, the model correctly predicts almost $60 \%$ of cases correctly (count $\mathrm{R}^{2}=0.599$ ). In table A2.3 in the appendix, we display the predicted probability of supporting a UBI when each independent variable is at its minimum versus maximum value. When exploitation concerns are held at their minimum value, this probability is $18 \%$ compared to $74 \%$ when it is held at its maximum value. For efficiency concerns, these numbers are $32 \%$ compared to $77 \%$. For repression concerns, the effect is negative so that when these concerns are at their minimum value the predicted probability is $67 \%$ compared to $48 \%$ when these concerns are at their maximum value.

We carry out a number of robustness checks. First, we rerun our analysis without including LGBTQ rights in our factor analysis. While we strongly believe that attitudes towards LGBTQ is a core part of the Left's political ideology, we want to provide an analysis with purely economic variables. The results, shown in section A3.1 in appendix, suggest our results are robust to this alternative specification. We find the same three factors and their effects shown in figure A3.1.2 are the same. 
Second, we reproduce our empirical analysis twice using two distinct deductive operationalisations of our three traditions. Indeed, as we now note in the appendix, we believe the more inductive logic underpinning our factor analysis represents a more transparent approach to capturing the different traditions. This approach also allows us to test the presence of different traditions in our survey data. However, one could nevertheless question the clarity of the factor analysis, especially since many variables load on the first factor (except pro-unemployed education). We therefore rerun the analysis with a deductive approach. Our deductive index of exploitation is a sum of the pro-redistribution, pro-equality and equal opportunity variables. Our deductive index of repression is a sum of equal opportunity variables, being free and pro-LGBT variables. Our deductive index of social investment approach is a sum of pro-childcare, pro-family benefits and pro-unemployed variables. As can be seen the three resulting indices have similar means and standard deviations. When regressing our dependent variable on these three new deductive indices while keeping the same controls as before, our key results are unchanged (see Figure A3.2.4 in the appendix). Note that equal opportunity is included in both the exploitation and repression indices because it seems important to both. However, we can also reproduce the same analysis while keeping this variable only in the exploitation index and excluding it from repression concerns index. The results in Figure A3.2.5 show that the findings for the three intellectual traditions of the Left remain similar.

Third, we consider it most important for our theoretical argument how respondents view themselves rather than how they vote, including whether they vote for left parties which can mean very different things in across political and party systems. That being said, we reproduce our analysis using past vote for left-wing parties as an alternative to selfidentification. To minimise concerns about comparability we focus on Western European countries only. A simple cross-tabulation reveals that more than $90 \%$ that identified as 
substantially left-leaning $(8,9$ and 10) on the left-right self-placement scale voted for a left party. Restricting our sample to left-wing voters in Western Europe, our factor analysis reveals the same three intellectual tradition of the Left: those with exploitation concerns score highly on pro-redistribution, pro-equality and equality of opportunities; those with efficiency concerns score most highly on childcare, family benefits and favouring education; while those with repression concerns score highly on being free, pro-LGBT rights, and equal opportunities. Rerunning our empirical analysis with the same estimation method and controls yields the same results as before (see Figure A3.5.1 in the appendix).

Fourth, in section A3.4 in the appendix, we replicate our analysis using ordinal logistic regression analysis on the non-binarized version of our dependent variable (Figure A3.4.1 in appendix) and an OLS linear probability model (Figure A3.4.2 in appendix). The key results remain unchanged.

Finally, we rerun our analysis for a larger sample including both left and right wing respondents (section A4.6 in appendix). Figure A4.6.1 shows that exploitation and efficiency concerns continue to be positively associated with higher support for UBI, whereas repression concerns are no longer statistically significant. In Figure A4.6.2, we show that left wing respondents are indeed more supportive of UBI than right wing respondents. Including our set of concerns reduces the effect of the left, consistent with the notion that these concerns capture a part of what it means to be left wing, but the effect remains significant. Controlling for being left does not change the association between exploitation and efficiency concerns with UBI. 


\section{Conclusion and discussion}

This article explores the relationship between support for UBI among left-wing individuals and different ideological strands of the political Left, captured by different concerns about capitalism. We argue that the nature of criticism against capitalism shapes the extent to which left-wing individuals will support a basic income. With this, our study contributes to the emerging literature on the drivers and conditions of support for UBI. The relevance left political ideology on welfare state support is underscored by a large political economy and political sociology literature (Linos and West, 2003; Jæger, 2006; Häusermann et al., 2016; Bremer and Schwander, 2019). Indeed, left-leaning citizens are more likely to be supportive of the UBI (Parolin and Siöland, 2020; Vlandas, 2020), but the UBI is nevertheless contested within the political Left (Van Parijs, 2018a). Disentangling and explaining this variation in support for UBI within the Left is the contribution of our study.

We base our analysis on the $8^{\text {th }}$ wave of the ESS (2016). A factor analysis reveals three factors that capture exploitation, repression and efficiency concerns as main sources of criticism about capitalism. We then test the extent to which these dimensions are associated with support for UBI. Our results confirms that not all left-leaning individuals are similar in their support for UBI and the type of concerns about capitalism matters for this variation. However, the relationship between different individuals with distinct views of the state and market appears empirically more complex than much of the theoretical-normative literature has so far implicitly assumed.

Indeed, both efficiency and exploitation concerns are associated with higher support for UBI among left-wing individuals, whereas repression concerns are associated with lower support. Thus, citizens who care about equality and redistribution are more supportive of UBI, despite the fact political thinkers in the Labourist traditions criticise UBI as an inadequate solution to the exploitative nature of capitalism (see for instance the contributions 
in van Parijs, 2018a). It seems that - in contrast to many arguments of Labourists' political elites - many left wing citizens consider the UBI as a desirable mean to fight poverty and inequality. Adherents of Social Investment who favour state interventions to address market failures and increase efficiency of markets tend to be more favourable to UBI. We suggest that both Social Investment policies and UBI are perceived as a modern, innovative idea as an alternative for the current welfare state (see also Roosma and van Oorschot 2020). The results for Libertarian Left do not conform to prior expectations (see van Parijs 2018c). In sum, we find support only for the expectation from the welfare state literature that Social Investment Left should be associated with UBI, but the opposite of what the political theory literature on UBI would make us expect: Labourists appear supportive whereas Left Libertarians appear less supportive of UBI. In that sense, our study challenges the normative literature on UBI: how can the opinions of Labourists' elites and citizens diverge so strongly?

Our findings are also relevant for welfare state scholars and from a policy-making perspective: without the support of the political Left, it seems unlikely that any government would implement UBI (see Chrisp and Martinelli (2019) and the contributions in Van Parijs (2018a)). Yet, given the heterogeneous support for UBI within the Left, one wonders about other possibly cross-cutting political coalitions that would enable an implementation of the policy. For instance, one might envisage social-liberal coalitions, which have successfully implemented Social Investment reforms in countries where the political Left alone did not achieve it (see for instance Kübler, 2007) but have not attracted much attention in the welfare state literature. Such a crosscutting coalition however entails the risk that only a meagre version of UBI would be implemented.

Our findings call for more extensive research on the sources of variation of UBI support within the political Left, the specific characteristics of UBI that trigger support or rejection by individuals espousing different ideological dimensions of the Left, and the 
potential coalition dynamics for a larger-scale introduction of UBI. We are also fully aware of the limitations of our analysis. It is entirely possible that part of our unexpected findings are due to imperfect empirical measurement of our main explanatory concepts for which we rely on the information given by the ESS. Yet, to the best of our knowledge, no alternative surveys offer more precise information about support for UBI and about different criticisms of capitalism, let alone a cross-national survey to control for country-differences in the structure of the welfare state and the economic system. Nevertheless, we acknowledge limitations with respect to our measurements. Our measurement of exploitation concern for instance is partly problematic because it appears to be closed related to general support of welfare state intervention. Thus, further research that might include data collection effort developing questions more closely linked to repression and repression concerns including variables that control for general welfare state support in a distinct way. 


\section{Figures and tables}

Table 1: Variation within the Left and Expectations

\begin{tabular}{|l|l|l|}
$\begin{array}{l}\text { Strands of Left } \\
\text { ideology }\end{array}$ & Main critique on capitalism & Proposed solution \\
\hline Labourists Left & Exploitation of labour & $\begin{array}{l}\text { Redistribution and collective } \\
\text { action }\end{array}$ \\
\hline Libertarian Left & Repression of labour & $\begin{array}{l}\text { De-commodification of labour, } \\
\text { real freedom }\end{array}$ \\
\hline $\begin{array}{l}\text { Social Investment } \\
\text { Left }\end{array}$ & $\begin{array}{l}\text { Inefficiency and under-investment } \\
\text { due to market failure }\end{array}$ & $\begin{array}{l}\text { Institutional change to facilitate } \\
\text { social investment }\end{array}$ \\
\hline
\end{tabular}


Table 2: Factor analysis on Left wing respondents

\begin{tabular}{|c|c|c|c|c|}
\hline Factor & Eigenvalue & Difference & Proportion & Cumulative \\
\hline Factor1 & 1.74145 & 0.52137 & 0.2177 & 0.2177 \\
\hline Factor2 & 1.22008 & 0.05202 & 0.1525 & 0.3702 \\
\hline Factor3 & 1.16806 & 0.2226 & 0.146 & 0.5162 \\
\hline Factor4 & 0.94546 & 0.10449 & 0.1182 & 0.6344 \\
\hline Factor5 & 0.84097 & 0.10374 & 0.1051 & 0.7395 \\
\hline Factor6 & 0.73723 & 0.01569 & 0.0922 & 0.8317 \\
\hline Factor7 & 0.72154 & 0.09634 & 0.0902 & 0.9218 \\
\hline Factor8 & 0.6252 & $\cdot$ & 0.0782 & 1 \\
\hline Variable & $\begin{array}{c}\text { Factor } 1 \\
\text { (Exploitation) }\end{array}$ & $\begin{array}{c}\text { Factor } 2 \\
\text { (Repression) }\end{array}$ & $\begin{array}{c}\text { Factor } 3 \\
\text { (Efficiency) }\end{array}$ & Uniqueness \\
\hline Pro-redistribution & 0.65 & -0.3749 & -0.0652 & 0.4328 \\
\hline Pro-equality & 0.6216 & -0.4104 & -0.0504 & 0.4427 \\
\hline Equal opportunity & 0.5994 & 0.339 & -0.2243 & 0.4756 \\
\hline Being free & 0.3294 & 0.5008 & -0.2464 & 0.5799 \\
\hline pro-LGBT & 0.3569 & 0.5102 & -0.3022 & 0.5209 \\
\hline Pro-childcare & 0.4527 & -0.1978 & 0.3586 & 0.6273 \\
\hline Pro-parents & 0.3629 & 0.1448 & 0.6967 & 0.362 \\
\hline Pro-unemployed & -0.0306 & 0.4743 & 0.5873 & 0.4292 \\
\hline
\end{tabular}

Note: Factor analysis/correlation; Number of observations $=9,727$. Method: principalcomponent factors; Retained factors $=3$; Rotation: (unrotated) Number of parameters $=21$; LR test: independent vs. saturated: $\operatorname{chi} 2(28)=4095.54$, Prob $>$ chi $2=0.0000$. 
Figure 1: Ideological dimensions and support for UBI among left wing respondents

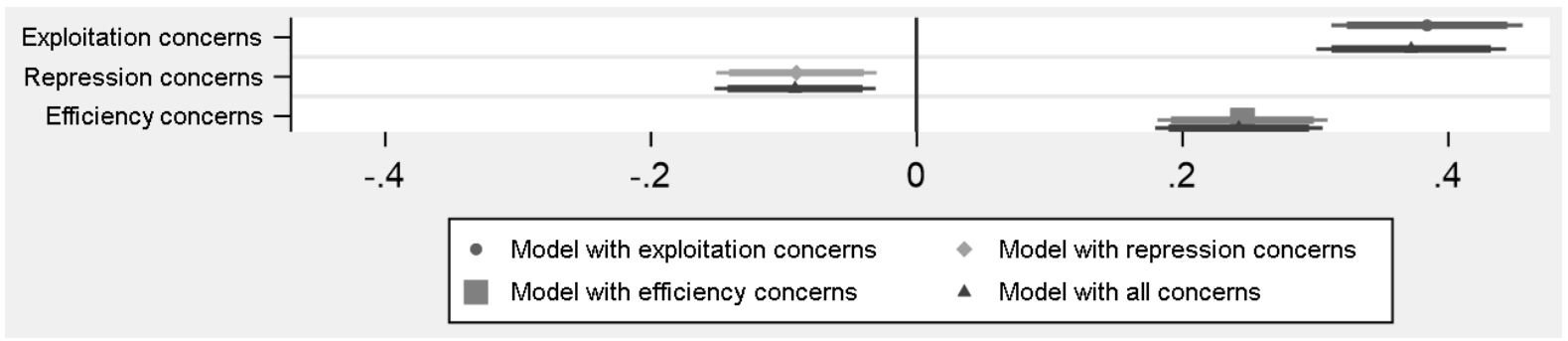

Note: The sample has been restricted to respondents who identify as left. This sample was then used to compute the factor analysis and run the above logistic regressions. Country fixed effects included but not shown, robust standard errors clustered by country ( $90 \%$ and $95 \%$ confidence intervals), the constant is positive but not statistically significant, Log pseudolikelihood $=-4268$. Countries included are as follow: Austria, Belgium, Czechia, Estonia, Finland, France, Germany, Hungary Iceland, Ireland, Italy, Lithuania, Netherlands, Norway, Poland, Portugal, Slovenia, Spain. Sweden, Switzerland, and United Kingdom. All coefficients are standardised so that they have a mean of 0 and a standard deviation of 1 , which makes them directly comparable. The following controls are included but not shown: age, gender, education, fixed term contract, income level, source of income, and occupation. Full results are shown in graphical form in figure A2.2, while the full regression results in tabular format are shown in table A2.3, both in appendix. 


\section{References}

Anderson CJ (2000) Economic voting and political context: a comparative perspective. Electoral Studies 19: 151-170.

Berman S (2009) The Primacy of Economics versus the Primacy of Politics: Understanding the Ideological Dynamics of the Twentieth Century. Perspectives on Politics 7(3): 561-578.

Bonoli G (2013) Origins of active social policy: labour market and childcare polices in a comparative perspective. Oxford: Oxford University Press.

Bremer B and Schwander H (2019) Green Voters and Support for Different Social Policy Logics in Times of Electoral Realignment. Paper presented at the Conference of Europeanists, June 20-24th, 2019 in Madrid.

Chrisp J and Martinelli L (2018) Robots are coming? Can the threat of automation drive public support for basic income? In: ESPAnet Annual Conference 2018, Vilnius, Lithuania.

Chrisp J and Martinelli L (2019) Neither Left Nor Right. In: Torry M (ed) The Palgrave International Handbook of Basic Income. London: Palgrave MacMillan, pp.477-492.

Clasen J and Clegg D (2012) Adapting Labour Market Policy to a Transformed Emplyoment structure: The Politics of 'Triple Integration'. In: Bonoli G and Natali D (eds) The Politics of the New Welfare State. Oxford: Oxford University Press.

Cusack T, Iversen T and Rehm P (2006) Risks at Work: The Demand and Supply Sides of Government Redistribution. Oxford Review of Economic Policy 22(3): 365-389.

Dimick M, Rueda D and Stegmueller D (2018) Models of Other-Regarding Preferences, Inequality, and Redistribution. Annual Review of Political Science 21(1): 441-460.

Eichhorst W, Kaufmann O and Konle-Seidl R (2008) Bringing the Jobless Into Work? Experiences with Activation Schemes in Europe and the US. Berlin: Springer Verlag.

Esping-Andersen G (2002) Why We Need a New Welfare State. Oxford: Oxford University Press.

Garritzmann J, Häusermann S and Palier B (forthcoming) The World Politics of Social Investment. Volume I: The Welfare State in the Century of Knowledge. Oxford: Oxford University Press.

Garritzmann JL, Busemeyer MR and Neimanns E (2018) Public demand for social investment: new supporting coalitions for welfare state reform in Western Europe? Journal of European Public Policy 25(6): 844-861.

Giddens A (1998) The Third Way: The Renewal of Social Democracy. Cambridge: Polity Press.

Haagh L (2018) Basic Income And Institutional Transformation. In: Van Parijs P (ed) Basic Income And The Left: A European Debate. London: Social Europe Edition, pp.78-88.

Hacker JS, Rehm P and Schlesinger M (2013) The Insecure American: Economic Experiences, Financial Worries, and Policy Attitudes. Perspectives on Politics 11(01): 23-49.

Hassel A (2016) Unconditional Basic Income Is A Dead End. In: Van Parijs P (ed) Basic Income and the Left. A European Debate. London: Social Europe Edition, pp.67-72.

Häusermann S, Kurer T and Schwander H (2015) High-skilled outsiders? Labor market vulnerability, education and welfare state preferences. Socio-Economic Review 13(2): 235-258.

Häusermann S, Kurer T and Schwander H (2016) Sharing the risk? Households, labor market vulnerability and social policy preferences in Western Europe. Journal of Politics 78(4): 1045-1060.

Hemerijck A (2017) The Uses of Social Investment. Oxford Oxford University Press. 
Hemerijck A (2018) Social investment as a policy paradigm. Journal of European Public Policy 25(6): 810-827.

Huber E and Stephens JD (2006) Combating new social risks. The Politics of Post-Industrial Welfare States.

Iversen T and Soskice D (2001) An Asset Theory of Social Policy Preferences. The American Political Science Review 95(4): 875-893.

Jæger MM (2006) What Makes People Support Public Responsibility for Welfare Provision: Self-interest or Political Ideology?:A Longitudinal Approach. Acta Sociologica 49(3): 321-338.

Jenson J (2012) A New Politics for the Social Investment Perspective: Objectives, Instruments, and Areas of Intervention in Welfare Regime. In: Bonoli G and Natali D (eds) The Politics of the New Welfare State. Oxford: Oxford University Press.

Keman H (2011) Third ways and social democracy: The right way to go? British Journal of Political Science 41(03): 671-680.

Kitschelt H (1994) The Transformation of the European Social Democracy. New York: Cambridge University Press.

Kitschelt HP (1988) Left-Libertarian Parties: Explaining Innovation in Competitive Party Systems. World Politics 40(2): 194-234.

Krebs A (2000) Why Mothers Should Be Fed. Analyse \& Kritik. 155.

Kübler D (2007) Understanding the Recent Expansion of Swiss Family Policy: An IdeaCentred Approach. Journal of Social Policy 36(2): 217 - 237.

Kvist J (2017) Inclusive Growth and Social investment s over the Life Course. In: Deeming C and Smyth P (eds) Reframing Global Social Policy: Social Investment for Sustainable and Inclusive Growth. Bristol: Policy Press, pp. 213-228.

Lee S (2018) Attitudes Toward Universal Basic Income and Welfare State in Europe: A Research Note. Basic Income Studies 13(1): 101-109.

Linos K and West M (2003) Self-interest, Social Beliefs, and Attitudes to Redistribution. Readdressing the Issue of Cross-national Variation. European Sociological Review 19(4): 393-409.

March L (2011) Radical left parties in Europe. Abingdon, Oxon: Routledge.

Margalit YM (2013) Explaining Social Policy Preferences: Evidence from the Great Recession. American Political Science Review 107(1): 80-103.

Mestrum F (2018) Why Basic Income Can Never Be A Progressive Solution - A Response To Van Parijs. In: Van Parijs P (ed) The Basic Income and the Left. A European Debate. London: Social Europe Edition, pp.21-27.

Michel H (2000) Sind Marktpreise gerecht? Analyse \& Kritik. 179.

Navarro V (2018) Why The Universal Basic Income Is Not The Best Public Intervention To Reduce Poverty Or Income Inequality. In: Van Parijs P (ed) Basic Income and the Left. A European Debate. London: Social Europe Edition.

Parolin Z and Siöland L (2020) Support for a universal basic income: A demand-capacity paradox? Journal of European Social Policy 30(1): 5-19.

Powell BK (2012) Two Libertarian Arguments for Basic Income Proposals. Basic Income Studies.

Przeworski A and Sprague J (1986) Paper Stones. A history of Electoral Socialism. Chicago: Chicago University Press.

Rehm P (2011) Social Policy by Popular Demands. World Politics 63(2): 271-299.

Roosma F and van Oorschot W (2018) Public opinion on basic income: Mapping European support for a radical alternative for welfare provision. In: ESPAnet Annual Conference 2018, Vilnius, Lithuania. 
Roosma F and van Oorschot W (2020) Public opinion on basic income: Mapping European support for a radical alternative for welfare provision. Journal of European Social Policy 30(2): 190-205.

Rothstein B (2018) UBI - A Bad Idea For The Welfare State. In: Van Parijs P (ed) Basic Income and the Left. A European Debate. London: Social Europe Edition, pp.103109.

Schwander H (2019) Labor market insecurity among the middle class: a cross-pressured group. Political Science Research and Methods. Epub ahead of print 2019/04/12. DOI: 10.1017/psrm.2019.11. 1-6.

Steinvorth U (2000) Kann das Grundeinkommen die Arbeitslosigkeit abbauen? Analyse \& Kritik. 257.

Van Parijs P (1995) Real Freedom for All: What (if Anything) Can Justify Capitalism? Oxford: Oxford University Press.

Van Parijs P (2018a) Basic Incme and the Left. A European Debate. Social Europe Edition.

Van Parijs P (2018b) Basic Income and the Left. A European Debate. London: Social Europe Edition.

Van Parijs P (2018c) Basic Income and the Left. A European Debate. In: Van Parijs P (ed) Basic Income and the Left. A European Debate. London: Social Europe Edition, pp.14.

Van Parijs P and Vanderborght Y (2017) Basic Income: A Radical Proposal for a Free Society and a Sane Economy. Cambridge, MA: Harvard University Press.

Vandenbroucke F (2001) European Social Democracy and the Third Way: Convergence, Divisions, and Shared Questions. In: White S (ed) New Labour: The Progressive Future? London: Palgrave Macmillan UK, pp.161-174.

Vlandas T (2013) Mixing apples with oranges? Partisanship and active labour market policies in Europe. Journal of European Social Policy 23(1): 3-20.

Vlandas T (2020) The political economy of individual-level support for the basic income in Europe. Journal of European Social Policy. DOI: 10.1177/0958928720923596. 0958928720923596.

Wilson R (2018) Universal Basic Income - A Disarmingly Simple Idea - And Fad. In: Van Parijs P (ed) Basic Income And The Left: A European Debate. London: Social Europe Edition, pp.61-66.

Zwolinski M (2013) Why Did Hayek Support a Basic Income? Libertarianism.org DEC 23, 2013. 


\section{Appendix}

September 2020

\section{The Left and Universal Basic Income: \\ The role of ideology in individual support}

\section{Table Contents}

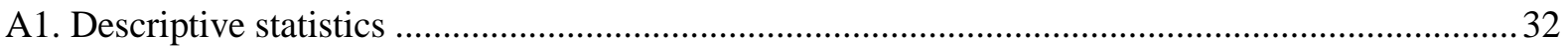

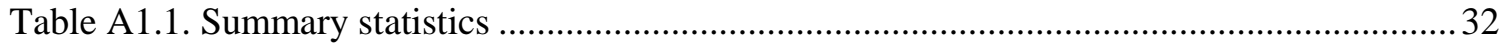

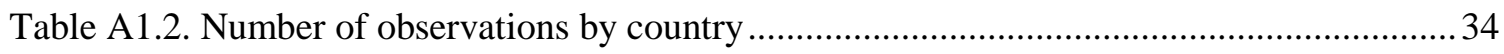

A2. Correlation between activation attitudes and UBI support ........................................................ 35

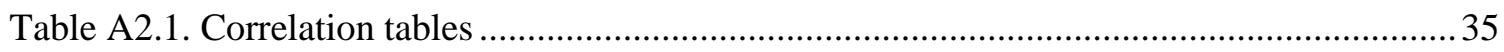

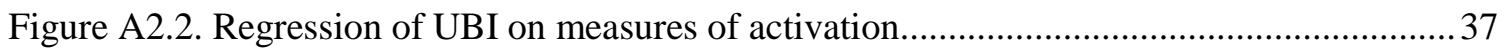

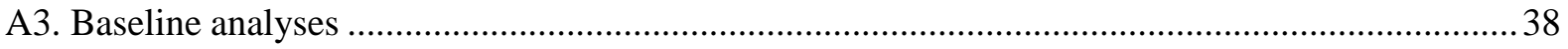

Table A3.1. Factor analysis among self-placed left wing respondents using principal component factors

Figure A3.2. Ideological dimensions and support for UBI among self-placed left wing respondents

Table A3.3. Full logistic regression results and predicted probabilities .42

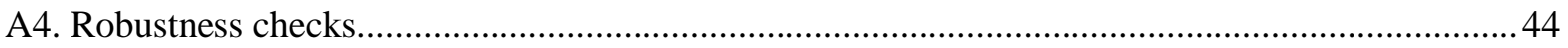

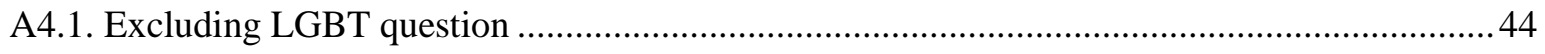


Table A4.1.1. Factor analysis among self-placed left wing respondents using principal component factors (without LGBT variable)

Figure A4.1.2. Ideological dimensions and support for UBI among self-placed left wing respondents .46

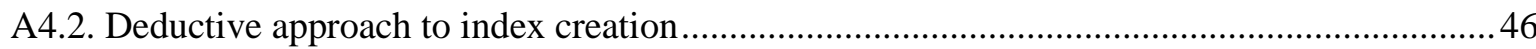

Table A4.2.1. Summary statistics of key independent variables and new deductive indices .47

Figure A4.2.2. Ideological dimensions using deductive indices and support for UBI among selfplaced left wing respondents. 48

Figure A4.2.3. Ideological dimensions using strictly exclusive deductive indices and support for UBI among self-placed left wing respondents

A4.3. Restricting analysis to sample of Western European countries 50

Figure A4.3.1. Ideological dimensions and support for UBI among self-placed left wing respondents (Western Europe sample)

A4.4. Alternative regression methods 51

Figure A4.4.1. Ordinal logistic 51

Figure A4.4.2. OLS regression for Linear Probability Model

A4.5. Using left wing voters to restrict sample to left individuals in Western European countries .52

Figure A4.5.1. Ideological dimensions and support for UBI among left wing voters .53

A4.6. Rerunning analysis on whole population (i.e. not restricted to left-wing respondents) 54

Figure A4.6.1. Ideological dimensions and support for UBI in whole population with no restrictions to left wing respondents

Figure A4.6.2. Ideological dimensions and support for UBI in whole population with no restrictions to left wing respondents and controlling for left self-placement 56 


\section{A1. Descriptive statistics}

Table A1.1. Summary statistics

\begin{tabular}{|c|c|c|c|c|c|}
\hline Variable & $\begin{array}{c}\text { Observation } \\
\text { s }\end{array}$ & Mean & $\begin{array}{l}\text { Standard } \\
\text { Deviation }\end{array}$ & $\begin{array}{c}\text { Minimu } \\
\text { m }\end{array}$ & $\begin{array}{c}\text { Maximu } \\
\text { m }\end{array}$ \\
\hline Dependent variable UBI & 36,355 & $\begin{array}{c}0.52482 \\
5\end{array}$ & 0.49939 & 0 & 1 \\
\hline Male & 39,391 & $\begin{array}{c}0.47632 \\
7\end{array}$ & 0.499446 & 0 & 1 \\
\hline Age & 39,272 & $\begin{array}{c}49.4341 \\
5\end{array}$ & 18.57078 & 15 & 100 \\
\hline Age (squared) & 39,272 & 2788.6 & 1881.314 & 225 & 10000 \\
\hline Education in years & 38,990 & $\begin{array}{c}13.0111 \\
8\end{array}$ & 3.915052 & 0 & 54 \\
\hline $\begin{array}{l}\text { Temporary contract } \\
\text { dummy }\end{array}$ & 29,271 & $\begin{array}{c}0.16569 \\
3\end{array}$ & 0.371811 & 0 & 1 \\
\hline Income & 32,647 & $\begin{array}{c}5.26869 \\
2\end{array}$ & 2.732017 & 1 & 10 \\
\hline \multicolumn{6}{|l|}{ Source of income } \\
\hline Self-employed & 38,832 & $\begin{array}{c}0.05662 \\
9\end{array}$ & 0.231135 & 0 & 1 \\
\hline Farmer & 38,832 & $\begin{array}{c}0.01138 \\
2\end{array}$ & 0.106081 & 0 & 1 \\
\hline Pensions & 38,832 & $\begin{array}{c}0.26702 \\
2\end{array}$ & 0.44241 & 0 & 1 \\
\hline Unemployed & 38,832 & $\begin{array}{c}0.02085 \\
9\end{array}$ & 0.142914 & 0 & 1 \\
\hline Other benefits & 38,832 & $\begin{array}{c}0.03010 \\
4\end{array}$ & 0.170876 & 0 & 1 \\
\hline Investor & 38,832 & $\begin{array}{c}0.00610 \\
3\end{array}$ & 0.077885 & 0 & 1 \\
\hline
\end{tabular}




\begin{tabular}{|l|c|c|c|c|c|}
\hline Other sources & 38,832 & 1 & 0.106672 & 0 & 1 \\
\hline Occupation & & & & & \\
\hline Professional & 35,703 & 4 & 0.38812 & 0 & 1 \\
\hline Technician & 35,703 & 9 & 0.356624 & 0 & 1 \\
\hline Clerical & 35,703 & 0.08764 & 0.282774 & 0 & 1 \\
\hline Service & 35,703 & 8 & 0.382019 & 0 & 1 \\
\hline Agriculture & 35,703 & 3 & 0.169187 & 0 & 1 \\
\hline Craft & & 0.17740 & & & 1 \\
\hline & 35,703 & 3 & 0.322415 & 0 & 1 \\
\hline Operator & 35,703 & 3 & 0.270635 & 0 & 1 \\
\hline & & 0.09595 & & 0 & \\
\hline
\end{tabular}


Table A1.2. Number of observations by country

\begin{tabular}{|c|c|c|c|}
\hline Country & Freq. & Percent & Cum. \\
\hline AT & 2,010 & 5.1 & 5.1 \\
\hline $\mathrm{BE}$ & 1,766 & 4.48 & 9.58 \\
\hline $\mathrm{CH}$ & 1,525 & 3.87 & 13.45 \\
\hline$C Z$ & 2,269 & 5.76 & 19.21 \\
\hline $\mathrm{DE}$ & 2,852 & 7.24 & 26.45 \\
\hline $\mathrm{EE}$ & 2,019 & 5.12 & 31.58 \\
\hline ES & 1,958 & 4.97 & 36.55 \\
\hline $\mathrm{FI}$ & 1,925 & 4.89 & 41.43 \\
\hline FR & 2,070 & 5.25 & 46.69 \\
\hline GB & 1,959 & 4.97 & 51.66 \\
\hline $\mathrm{HU}$ & 1,614 & 4.1 & 55.75 \\
\hline $\mathrm{IE}$ & 2,757 & 7 & 62.75 \\
\hline IS & 880 & 2.23 & 64.98 \\
\hline IT & 2,626 & 6.66 & 71.65 \\
\hline LT & 2,122 & 5.39 & 77.04 \\
\hline $\mathrm{NL}$ & 1,681 & 4.27 & 81.3 \\
\hline NO & 1,545 & 3.92 & 85.22 \\
\hline $\mathrm{PL}$ & 1,694 & 4.3 & 89.52 \\
\hline $\begin{array}{l}\text { PT } \\
\end{array}$ & 1,270 & 3.22 & 92.75 \\
\hline SE & 1,551 & 3.94 & 96.68 \\
\hline $\mathrm{SI}$ & 1,307 & 3.32 & 100 \\
\hline
\end{tabular}




\begin{tabular}{|l|l|l|l|}
\hline Total & 39,400 & 100 & \\
\hline
\end{tabular}

\section{A2. Correlation between activation attitudes and UBI support}

When discussing our analyses, we mention in footnote 3 (p. 11) that the relationship between attitudes towards activation and UBI is negative. Here we discuss the variables and results for this claim in more details. To capture activation, we rely on three distinct variables which capture attitudes about penalising the unemployed by reducing their benefits if they refuse a job for three possible reasons: "Unemployment benefits if turn down job because of less pay" (ubpay), "Unemployment benefits if turn down job because of lower level of education" (ubedu), and "Unemployment benefits if turn down job because it is unpaid" (ubunp). Each variable is scaled from 1 "Should lose all unemployment benefit" to 4 "Should keep all unemployment benefits" and therefore more positive values capture less activation.

As can be seen in table A2.1 below, less activation attitudes is always positively correlated with more support for UBI: while the correlation is not always very strong, it is always statistically significant. If we run a more formal logistic regression analysis controlling for other key variables, the results are the same: lower activation attitudes are positively and significantly related with support for a UBI (see figure A2.2).

Table A2.1. Correlation tables

\begin{tabular}{|l|l|l|l|l|}
\hline Western Europe & & & & \\
\hline & Ubpay & Ubedu & Ubnp & UBI \\
\hline Ubpay & 1 & & & \\
\hline
\end{tabular}




\begin{tabular}{|l|l|l|l|l|}
\hline Ubedu & 0.6734 & 1 & & \\
& $(0.000)$ & & & \\
\hline Ubnp & 0.4028 & 0.4413 & 1 & \\
\hline UBI & $0.000)$ & $(0.000)$ & & \\
\hline All sample & 0.1180 & 0.1025 & 0.1012 & 1 \\
\hline & $(0.000)$ & $(0.000)$ & $(0.000)$ & \\
\hline Ubpay & 1 & & & \\
\hline Ubedu & 0.6905 & 1 & & \\
\hline UBI & $(0.000)$ & & & \\
\hline Ubnp & 0.4422 & 0.4633 & 1 & \\
& $(0.000)$ & $(0.000)$ & & \\
\hline & 0.0762 & 0.0699 & 0.0574 & 1 \\
& $(0.000)$ & $(0.000)$ & $(0.000)$ & \\
\hline
\end{tabular}

36 
Figure A2.2. Regression of UBI on measures of activation

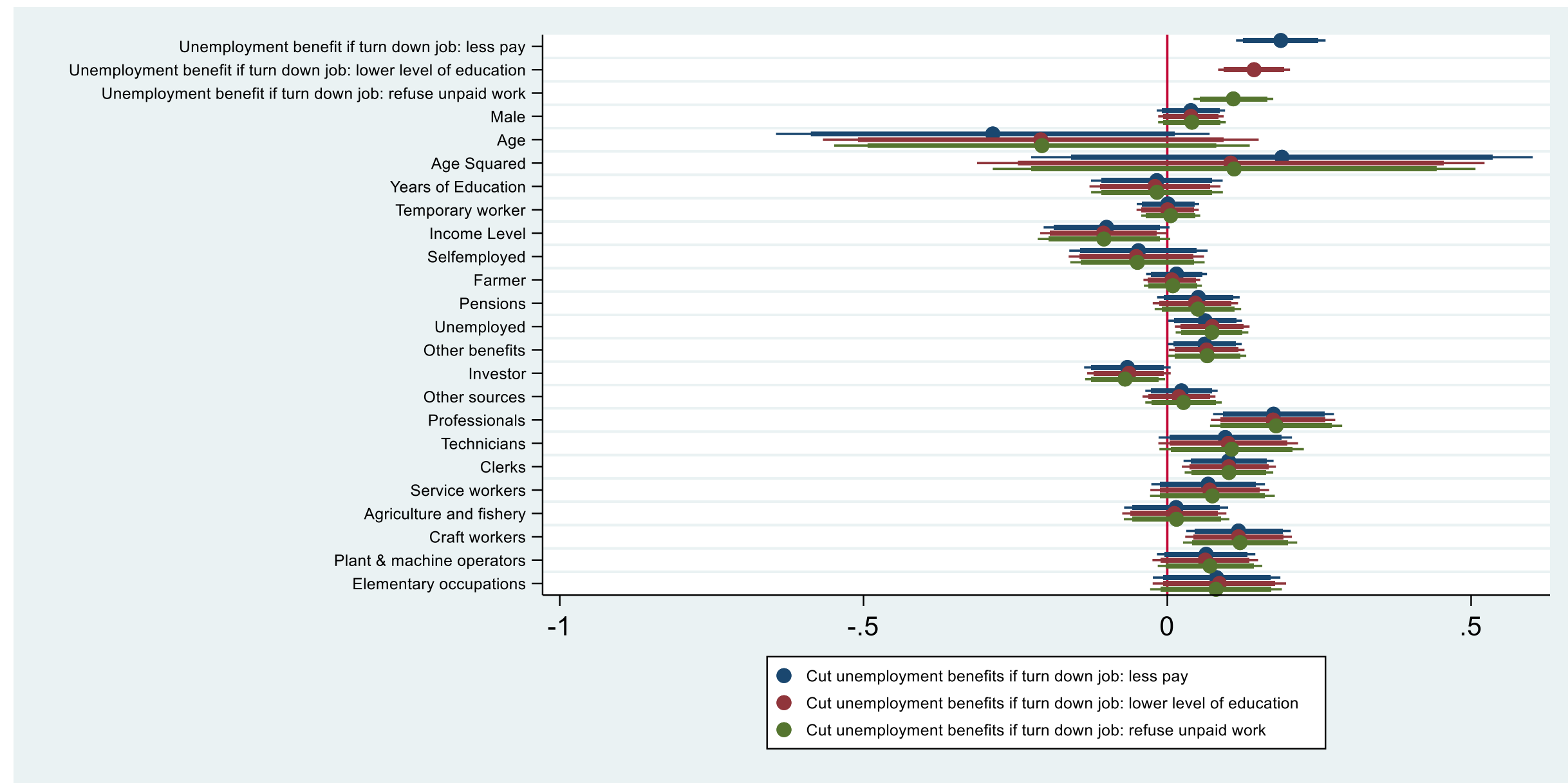




\section{A3. Baseline analyses}

Table A3.1 displays in full the results from the factor analysis and figure A3.2 shows the results for all independent variables, while Table A3.3 displays the full logistic regression results. Our three key indices of left wing tradition "exploitation", "repression and "social investment" together have very strong predictive power as shown when running a simple logistic regression of support for UBI on three variables. The count R2, which captures the percentage of correct predictions of the model is 0.599 .9

Table A3.3 also displays all the predicted probabilities for the minimum versus maximum values of each independent variable while holding the controls at their mean value. Exploitation concerns have the most effect on support on UBI: those with highest concerns have roughly $75 \%$ predicted probability (95\% CI between $71 \%$ and $77 \%$ ) of supporting UBI compared to only $18 \%$ for those with lowest concerns (95\% CI between $13 \%$ and $23 \%$ ). Second, those with the highest level of efficiency concerns have $77 \%$ predicted probability (95\% confidence interval between $73 \%$ and $82 \%$ ) of support compared to $32 \%$ for those with lowest level of concerns (95\% confidence interval between $26 \%$ and $37 \%$ ). Third, those with high repression concerns have a predicted probability of $48 \%$ compared to $67 \%$ for those with low concerns. Even this 19 percentage points gap compares favourability to many of the other variables that have

\footnotetext{
9 “Count R-Square treats any record with a predicted probability of .5 or greater as having a predicted outcome of 1 and any record with a predicted probability less than .5 as having a predicted outcome of 0 . Then, the predicted $1 \mathrm{~s}$ that match actual $1 \mathrm{~s}$ and predicted $0 \mathrm{~s}$ that match actual $0 \mathrm{~s}$ are tallied. This is the number of records correctly predicted, given this cutoff point of .5. The R-square is this correct count divided by the total count." Accessed in July 2020 from: https://stats.idre.ucla.edu/other/mult-pkg/faq/general/faq-what-are-pseudo-r-squareds/
} 
been identified as important in the literature: for income the gap is 12 points; for temporary work 6 points; for age 5 points; and for gender 6 points. 
Table A3.1. Factor analysis among self-placed left wing respondents using principal component factors

\begin{tabular}{|c|c|c|c|c|}
\hline Factor & Eigenvalue & Difference & Proportion & Cumulative \\
\hline Factor1 & 1.74145 & 0.52137 & 0.2177 & 0.2177 \\
\hline Factor2 & 1.22008 & 0.05202 & 0.1525 & 0.3702 \\
\hline Factor3 & 1.16806 & 0.2226 & 0.146 & 0.5162 \\
\hline Factor4 & 0.94546 & 0.10449 & 0.1182 & 0.6344 \\
\hline Factor5 & 0.84097 & 0.10374 & 0.1051 & 0.7395 \\
\hline Factor6 & 0.73723 & 0.01569 & 0.0922 & 0.8317 \\
\hline Factor7 & 0.72154 & 0.09634 & 0.0902 & 0.9218 \\
\hline Factor8 & 0.6252 & . & 0.0782 & 1 \\
\hline Variable & $\begin{array}{c}\text { Factor 1 } \\
\text { (Exploitation) }\end{array}$ & $\begin{array}{c}\text { Factor } 2 \\
\text { (Repression) }\end{array}$ & $\begin{array}{c}\text { Factor } 3 \\
\text { (Efficiency) }\end{array}$ & Uniqueness \\
\hline Pro-redistribution & 0.65 & -0.3749 & -0.0652 & 0.4328 \\
\hline Pro-equality & 0.6216 & -0.4104 & -0.0504 & 0.4427 \\
\hline Equal opportunity & 0.5994 & 0.339 & -0.2243 & 0.4756 \\
\hline Being free & 0.3294 & 0.5008 & -0.2464 & 0.5799 \\
\hline pro-LGBT & 0.3569 & 0.5102 & -0.3022 & 0.5209 \\
\hline Pro-childcare & 0.4527 & -0.1978 & 0.3586 & 0.6273 \\
\hline Pro-parents & 0.3629 & 0.1448 & 0.6967 & 0.362 \\
\hline Pro-unemployed & -0.0306 & 0.4743 & 0.5873 & 0.4292 \\
\hline
\end{tabular}

Note: Factor analysis/correlation; Number of observations $=9,727$. Method: principalcomponent factors; Retained factors $=3$; Rotation: (unrotated) Number of paramaters $=21$; LR test: independent vs. saturated: chi2(28) $=4095.54$, Prob $>$ chi $2=0.0000$. 
Figure A3.2. Ideological dimensions and support for UBI among self-placed left wing respondents

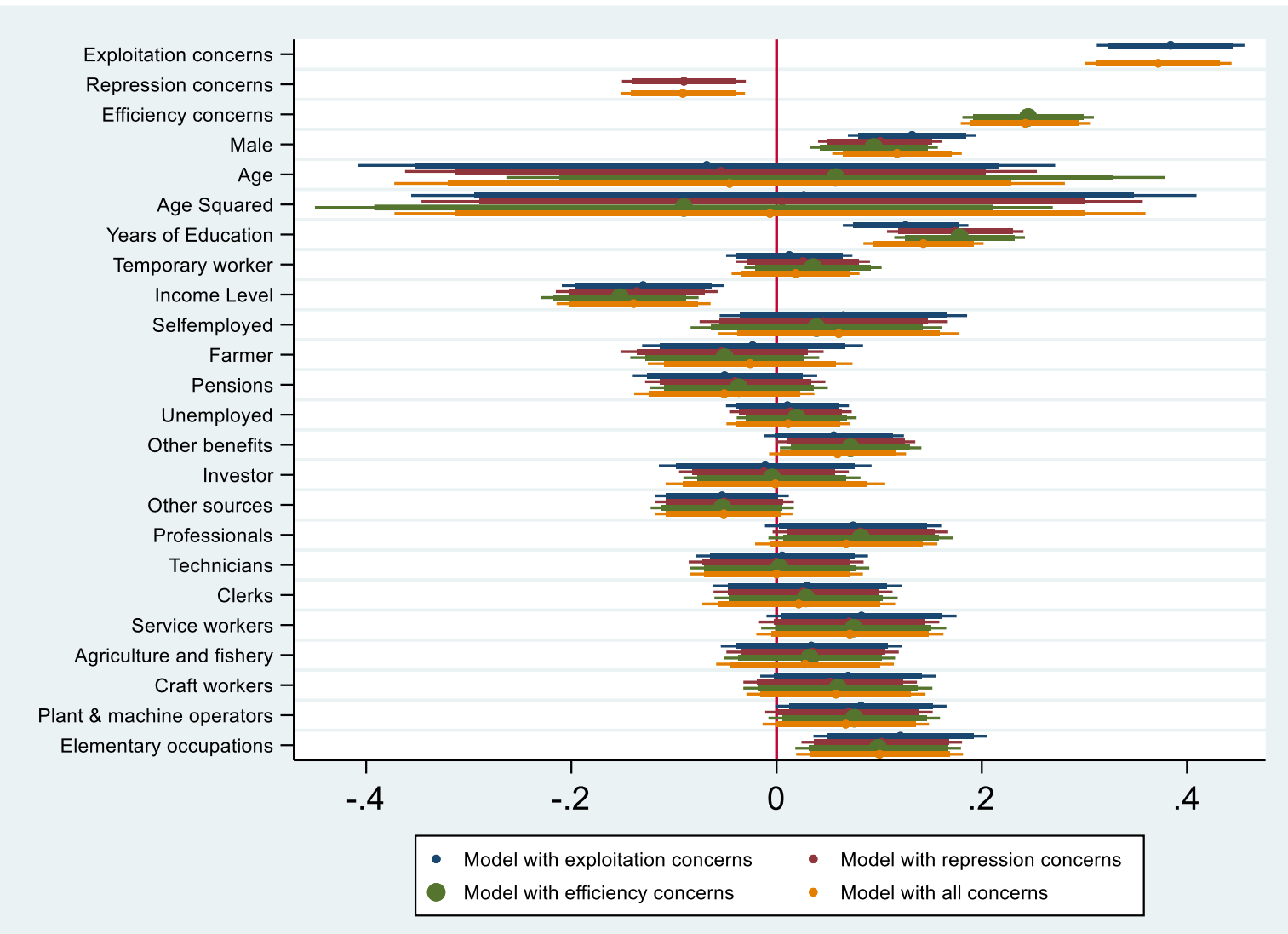

Note: The sample has been restricted to respondents who identify as left. This sample was then used to compute the factor analysis and run the above logistic regressions. Country fixed effects included but not shown, robust standard errors clustered by country $(90 \%$ and $95 \%$ confidence intervals), the constant is positive but not statistically significant, Log pseudolikelihood = 4268. Countries included are as follow: Austria, Belgium, Czechia, Estonia, Finland, France, Germany, Hungary Iceland, Ireland, Italy, Lithuania, Netherlands, Norway, Poland, Portugal, Slovenia, Spain. Sweden, Switzerland, and United Kingdom. All coefficients are standardised so that they have a mean of 0 and a standard deviation of 1 , which makes them directly comparable. 
Table A3.3. Full logistic regression results and predicted probabilities

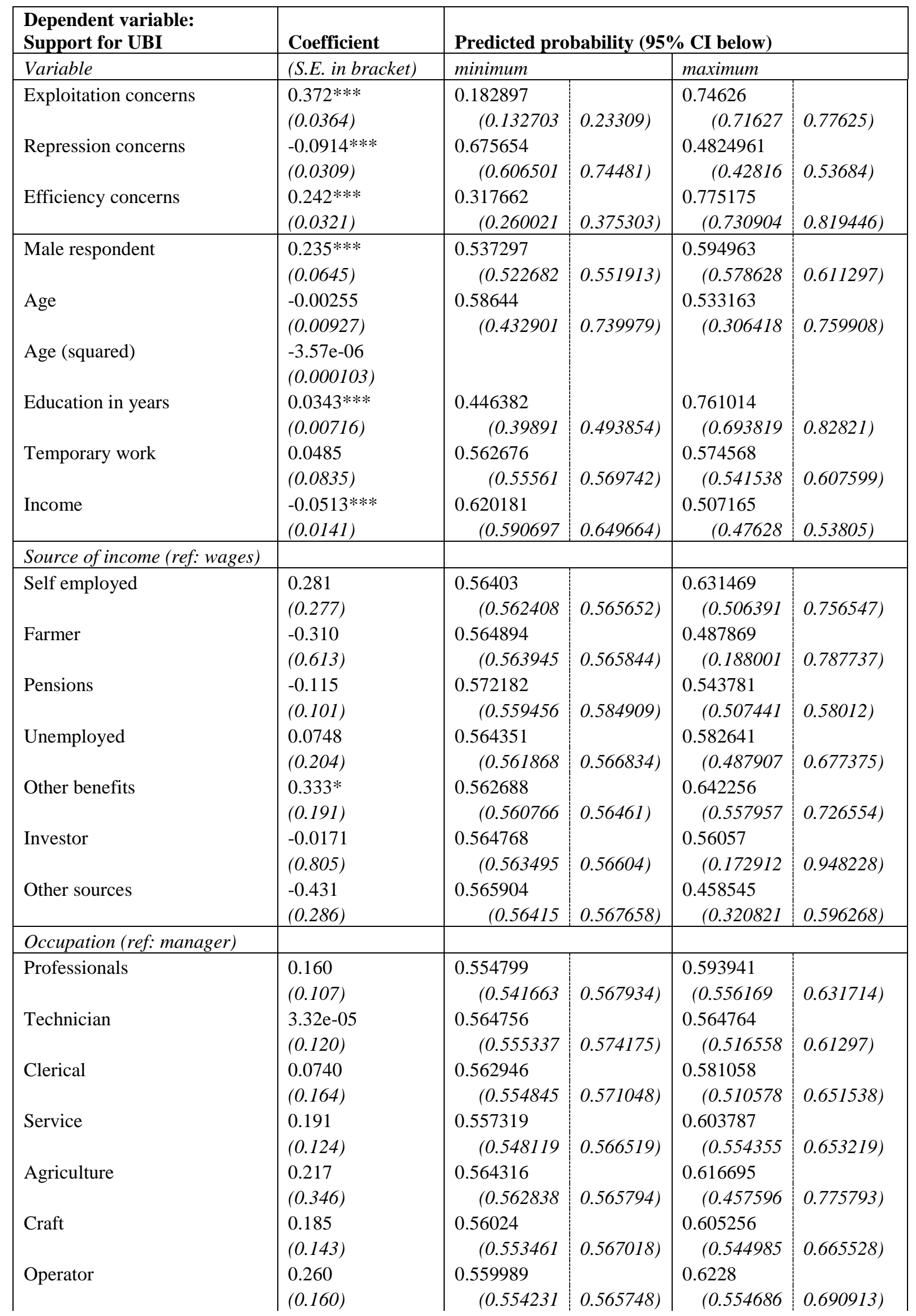




\begin{tabular}{|l|l|l|l|l|l|}
\hline $\begin{array}{l}\text { Dependent variable: } \\
\text { Support for UBI }\end{array}$ & Coefficient & \multicolumn{3}{|l|}{ Predicted probability (95\% CI below) } \\
\hline Variable & S.E. in bracket) & minimum & maximum & \\
\hline Elementary & $0.358^{* *}$ & 0.557238 & & 0.642794 & \\
& $(0.148)$ & $(0.551545$ & $0.562931)$ & $(0.581561$ & $0.704028)$ \\
\hline Constant & -0.183 & & & \\
& $(0.232)$ & & & \\
Log pseudo likelihood & -4272.4601 & & & & \\
Observations & 6,652 & & & \\
Pseudo R-squared & 0.0638 & & & \\
\hline
\end{tabular}

Note: Robust standard errors clustered by country shown in parentheses, country fixed effects included but not shown. $* * * p<0.01, * * p<0.05, * p<0.1$ 


\section{A4. Robustness checks}

\section{A4.1. Excluding LGBT question}

Because the survey questions in the European Social Survey only measure the three distinct intellectual traditions imperfectly at best, we carry out a number of robustness checks to test the fragility of our results. First, while we believe both economic and cultural variables are needed to appropriately capture the different intellectual traditions of the left, we replicate the analysis while excluding attitudes towards LGBTQ rights. As can be observed in table A4.1.1 the resulting factor analysis yields similar results. Using these new factors, we reproduce the baseline results and our findings hold (see figure A4.1.2).

Table A4.1.1. Factor analysis among self-placed left wing respondents using principal component factors (without LGBT variable)

\begin{tabular}{|l|c|c|c|c|}
\hline Factor & Eigenvalue & Difference & Proportion & Cumulative \\
\hline Factor1 & 1.69 & 0.50 & 0.24 & 0.24 \\
\hline Factor2 & 1.19 & 0.09 & 0.17 & 0.41 \\
\hline Factor3 & 1.09 & 0.17 & 0.15 & 0.56 \\
\hline Factor4 & 0.92 & 0.16 & 0.13 & 0.70 \\
\hline Factor5 & 0.76 & 0.02 & 0.11 & 0.81 \\
\hline Factor6 & 0.73 & 0.11 & 0.10 & 0.91 \\
\hline Factor7 & 0.62 & & 0.09 & 1.000 \\
\hline
\end{tabular}

\begin{tabular}{|l|c|c|c|c|}
\hline Variable & $\begin{array}{c}\text { Factor 1 } \\
\text { (Exploitation) }\end{array}$ & $\begin{array}{c}\text { Factor 2 } \\
\text { (Repression) }\end{array}$ & $\begin{array}{c}\text { Factor 3 } \\
\text { (Efficiency) }\end{array}$ & Uniqueness \\
\hline Pro-redistribution & 0.6881 & -0.1677 & -0.2742 & 0.4232 \\
\hline Pro-equality & 0.6592 & -0.2336 & -0.295 & 0.4239 \\
\hline Equal opportunity & 0.5416 & 0.4988 & 0.0815 & 0.4513 \\
\hline
\end{tabular}




\begin{tabular}{|l|c|c|c|c|}
\hline Being free & 0.2765 & 0.784 & 0.1812 & 0.276 \\
\hline Pro-childcare & 0.504 & -0.2285 & 0.1669 & 0.6659 \\
\hline Pro-parents & 0.388 & -0.2796 & 0.6342 & 0.369 \\
\hline Pro-unemployed & -0.0554 & -0.1102 & 0.7456 & 0.4289 \\
\hline
\end{tabular}

Note: Factor analysis/correlation; Number of observations $=9,803$. Method: principalcomponent factors; Retained factors $=3$; Rotation: (unrotated) Number of paramaters $=18$; LR test: independent vs. saturated: chi2 21$)=3518$, Prob $>$ chi $2=0.0000$. 
Figure A4.1.2. Ideological dimensions and support for UBI among self-placed left wing respondents

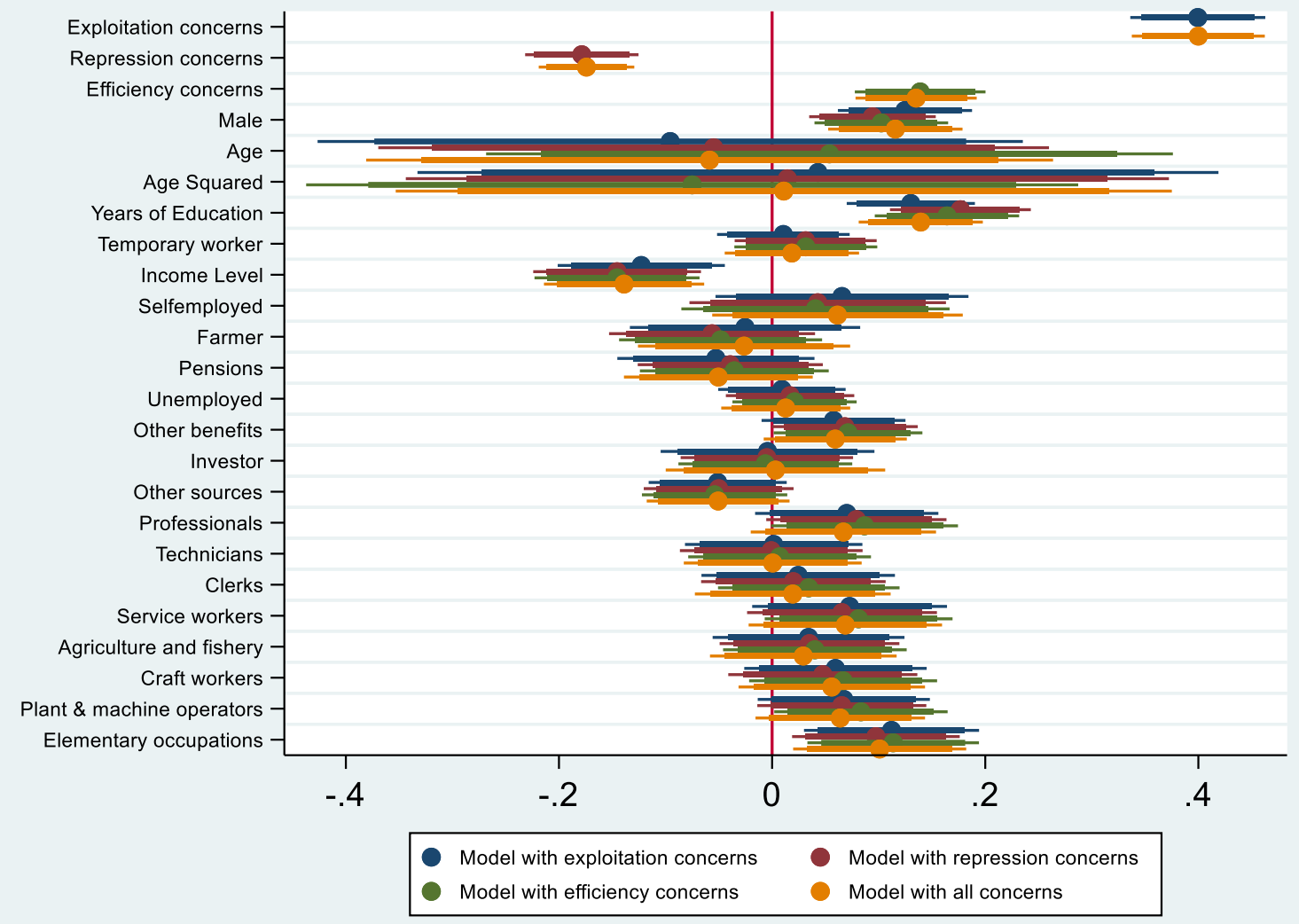

\section{A4.2. Deductive approach to index creation}

Next, we believe the more inductive logic underpinning our factor analysis represents a more transparent approach to capturing the different traditions. This approach also allows us to test the presence of different traditions in our survey data. However, one could nevertheless question the clarity and rationale behind the factor analysis, especially since many variables load on the first factor (except pro-unemployed education). We therefore rerun the analysis using a deductive approach to selecting which variables capture which intellectual tradition. This deductive approach still allows us to account for the distinct emphasis of each tradition while representing a valuable robustness check. 
We first summarise the mean, standard deviation, minimum and maximum values of all our key variables in table A4.2.1 below. The last three rows then display our three deductive index that are calculated as follows. First, our deductive index of exploitation is a sum of the proredistribution, pro-equality and equal opportunity variables. Second our deductive index of repression is a sum of equal opportunity variables, being free and pro-LGBT variables. Third, our deductive index of social investment approach is a sum of pro-childcare, pro-family benefits and pro-unemployed variables. As can be seen the three resulting indices have similar means and standard deviations. When regressing our dependent variable on these three new deductive indices while keeping the same controls as before, our key results are unchanged (see Figure A4.2.2).

Note that equal opportunity is included in both the exploitation and repression indices because it seems important to both. However, we can also reproduce the same analysis while keeping this variable only in the exploitation index and excluding it from repression concerns index. The results in Figure A4.2.3 show that the findings for the three intellectual traditions of the Left remain similar.

Table A4.2.1. Summary statistics of key independent variables and new deductive indices

\begin{tabular}{|l|c|c|c|c|c|}
\hline Variable & Observations & Mean & $\begin{array}{l}\text { Standard } \\
\text { deviation }\end{array}$ & Minimum & Maximum \\
\hline $\begin{array}{l}\text { Pro- } \\
\text { redistribution }\end{array}$ & 38,835 & 3.86 & 0.99 & 1 & 5 \\
\hline Pro-equality & 38,817 & 3.60 & 0.95 & 1 & 5 \\
\hline $\begin{array}{l}\text { Equal } \\
\text { opportunity }\end{array}$ & 38,819 & 4.84 & 1.06 & 1 & 6 \\
\hline Being free & 38,846 & 4.83 & 1.08 & 1 & 6 \\
\hline pro-LGBT & 38,540 & 3.98 & 1.12 & 1 & 5 \\
\hline Pro-childcare & 38,940 & 7.84 & 2.06 & 0 & 10 \\
\hline Pro-parents & 36,554 & 2.59 & 0.73 & 1 & 4 \\
\hline Pro-unemployed & 36,783 & 2.71 & 0.74 & 1 & 4 \\
\hline $\begin{array}{l}\text { Exploitation } \\
\text { deductive index }\end{array}$ & 37,940 & 12.30 & 2.11 & 3 & 16 \\
\hline
\end{tabular}




\begin{tabular}{|l|c|c|c|c|c|}
\hline $\begin{array}{l}\text { Repression } \\
\text { deductive index }\end{array}$ & 37,935 & 13.66 & 2.18 & 3 & 17 \\
\hline $\begin{array}{l}\text { Social } \\
\text { investment } \\
\text { deductive index }\end{array}$ & 34,842 & 13.13 & 2.45 & 2 & 18 \\
\hline
\end{tabular}

Figure A4.2.2. Ideological dimensions using deductive indices and support for

UBI among self-placed left wing respondents

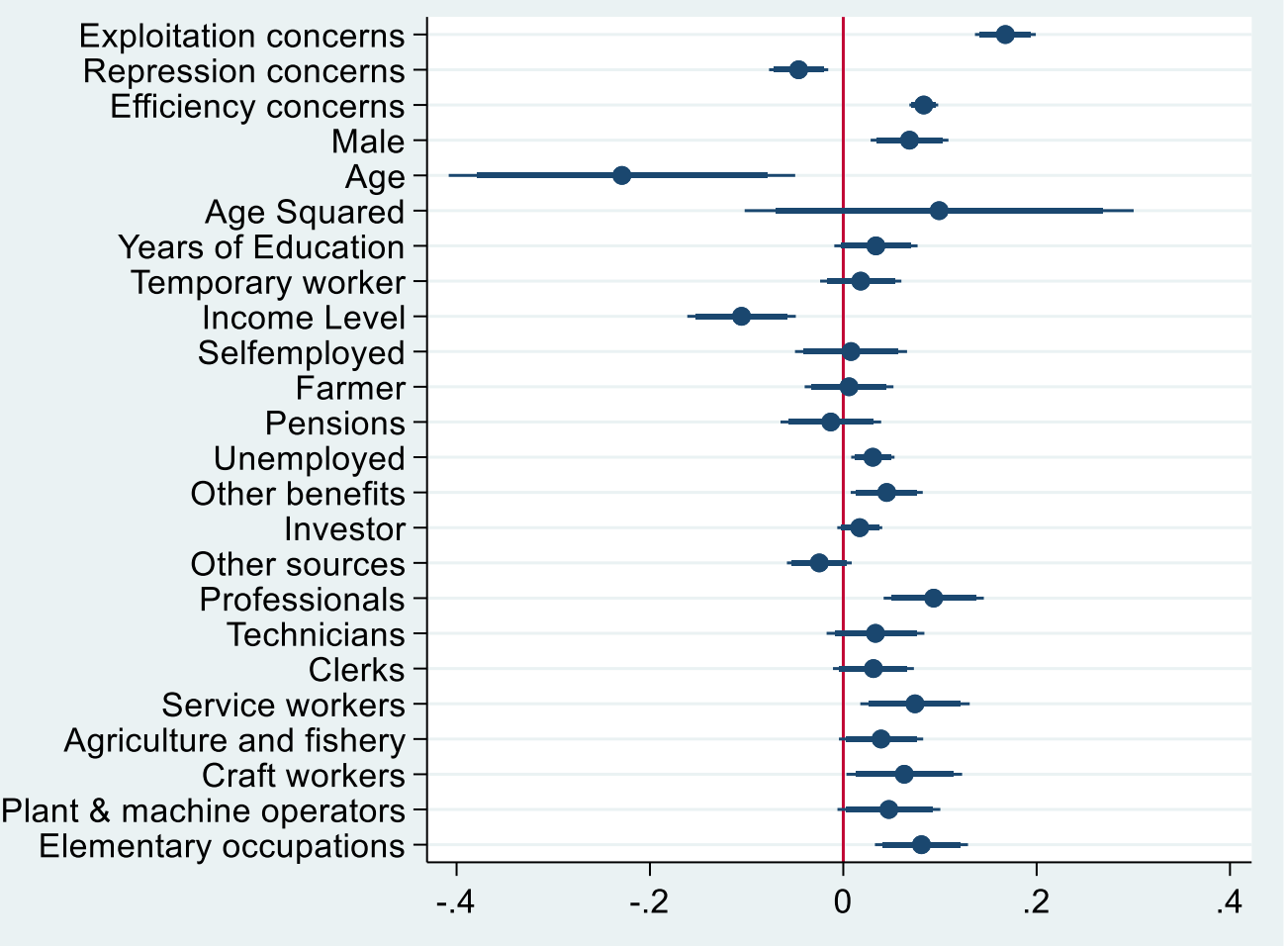


Figure A4.2.3. Ideological dimensions using strictly exclusive deductive indices and support for UBI among self-placed left wing respondents

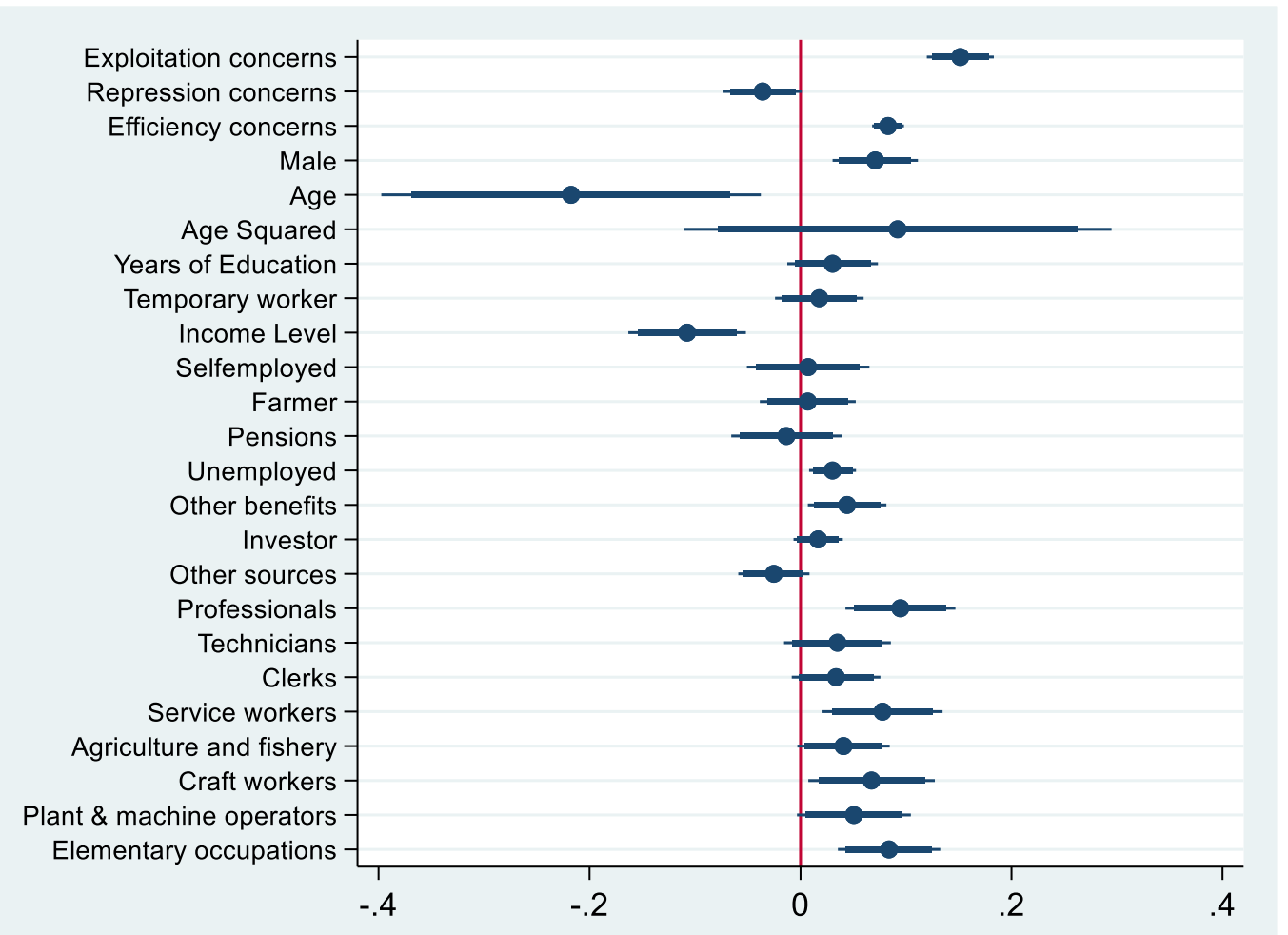

Note: repression concerns are statistically significant at $10 \%$ level ( $p$-value $=0.057)$. 


\section{A4.3. Restricting analysis to sample of Western European countries}

Despite clear historical and socio-political differences between Western and Eastern European countries we decided to keep both in our baseline analyse to maximise sample size. However, if we restrict our analysis to Western Europe, our results remain the same (see Figure A4.3.1).

Figure A4.3.1. Ideological dimensions and support for UBI among self-placed left wing respondents (Western Europe sample)

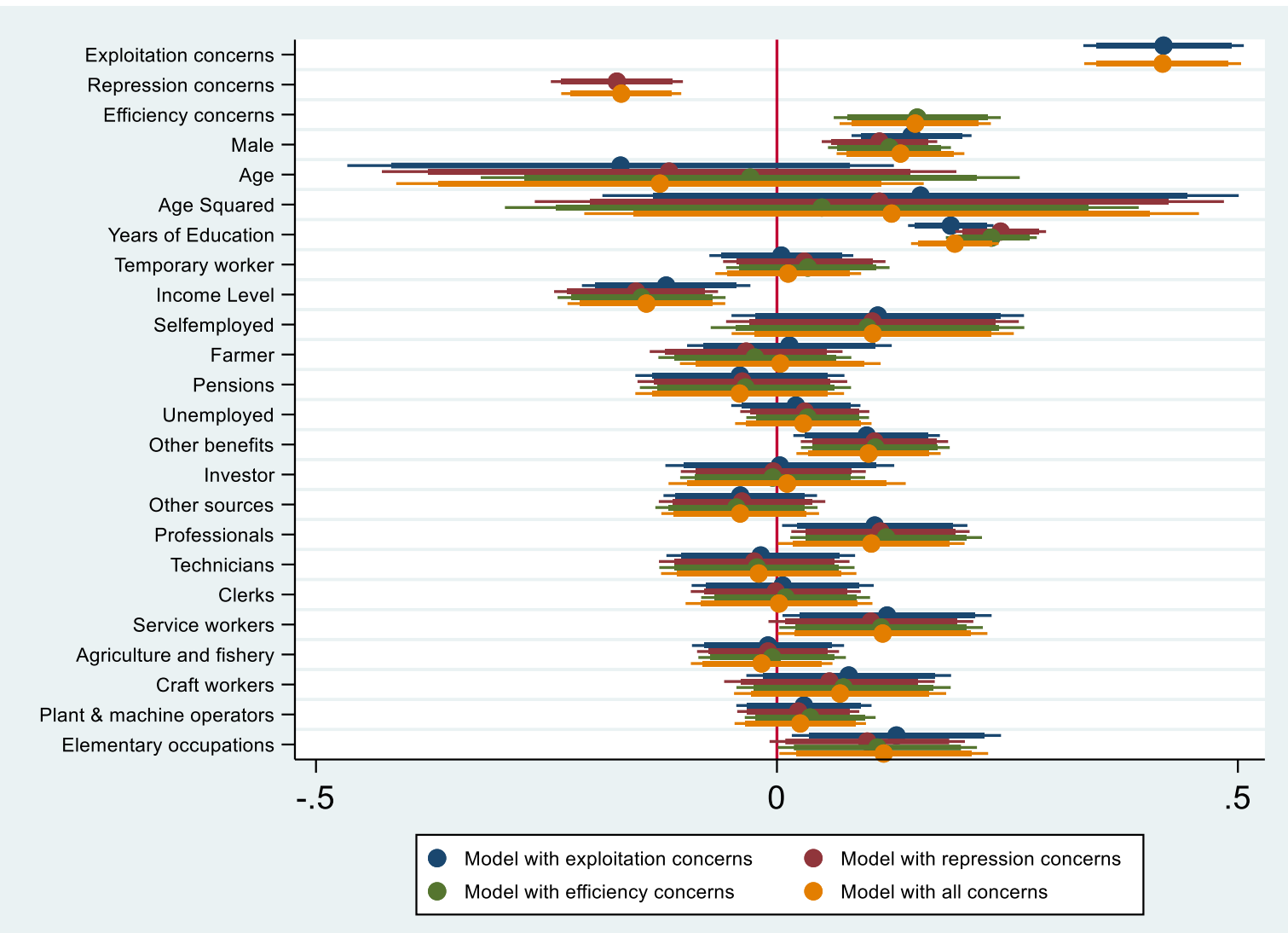




\section{A4.4. Alternative regression methods}

In this section we replicate our analysis using ordinal logistic regression analysis on the non-

binarised version of our dependent variable (Figure A4.4.1) and an OLS linear probability

model (Figure A4.4.2). The key results remain unchanged.

Figure A4.4.1. Ordinal logistic

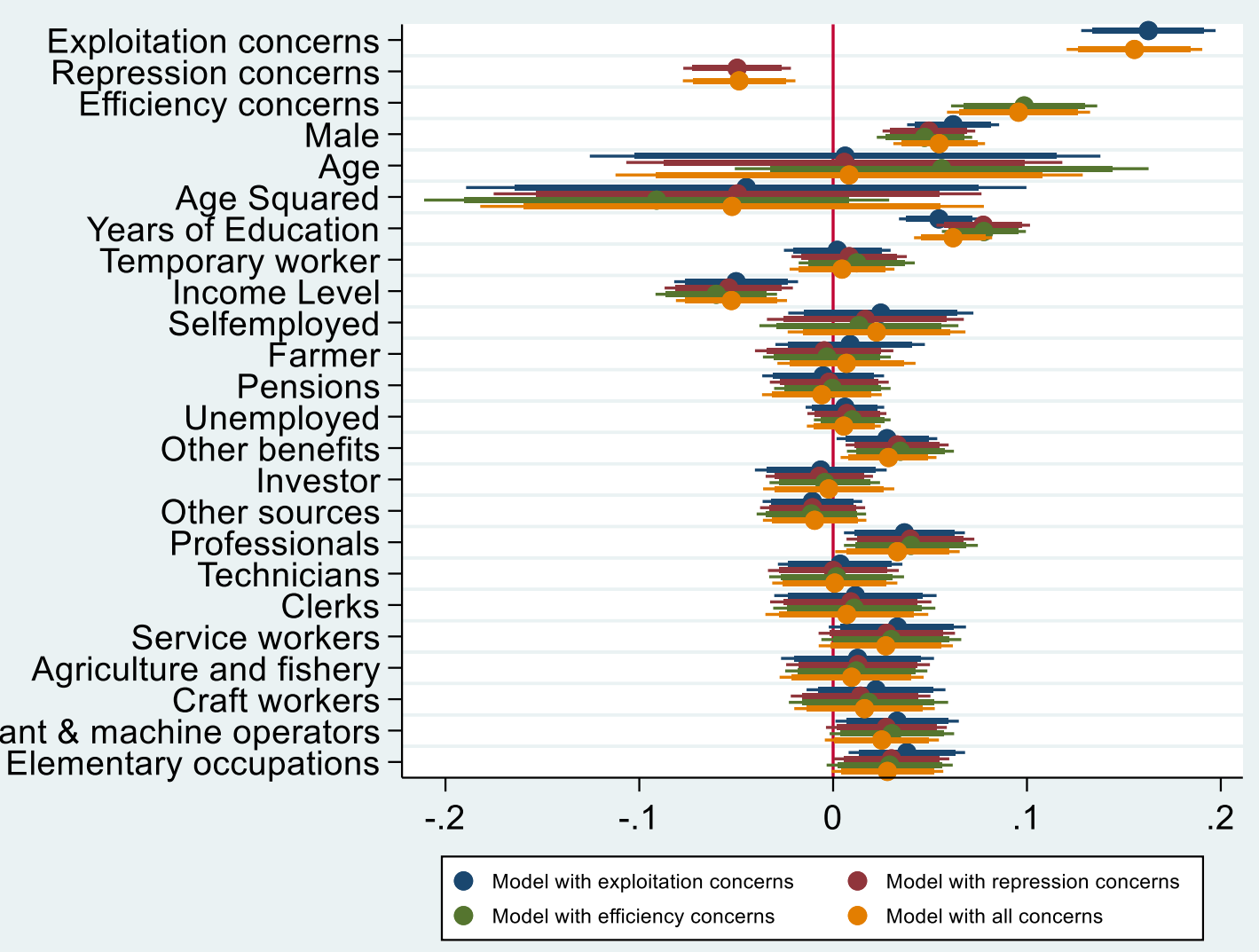




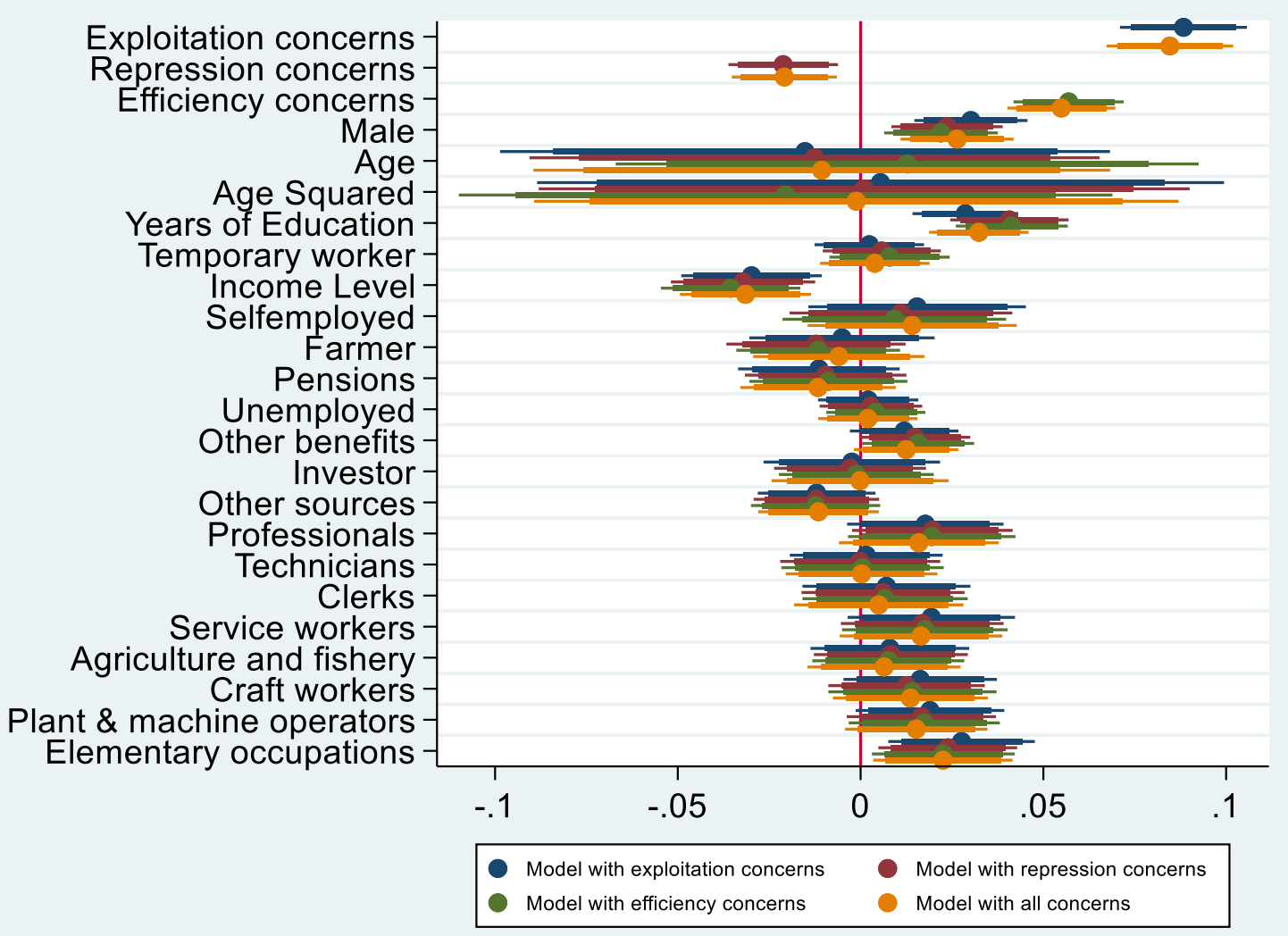

\section{A4.5. Using left wing voters to restrict sample to left individuals in Western}

\section{European countries}

What matters for our theoretical argument is how respondents view themselves rather than how they vote, including whether they vote for left wing parties which can mean very different things in across political and party systems. That being said, one could also reasonably question whether self-placement is sufficiently precise in identifying left wing respondents. We therefore reproduce our analysis using past vote for left wing parties as an alternative. To minimise concerns about comparability we focus on Western European countries only. The correlation between self-placement on the left and voting for a left wing, is a strong but not particularly high 0.51 with p-value equal to 0.000 . On the other hand, a simple cross-tabulation reveals that more than $90 \%$ that identified as most left $(8,9$ and 10) on the left-right self-placement scale voted for a left wing party. Restricting our sample to left wing voters in Western Europe, our 
factor analysis reveals the same three intellectual tradition of the left: those with exploitation concerns score highly on pro-redistribution, pro-equality and equality of opportunities; those with efficiency concerns score most highly on childcare, family benefits and favouring education; while those with repression concerns score highly on being free, pro-LGBT rights, and equal opportunities. Rerunning our empirical analysis with the same estimation method and controls yields the same results as before (see Figure A4.5.1).

\section{Figure A4.5.1. Ideological dimensions and support for UBI among left wing}

voters

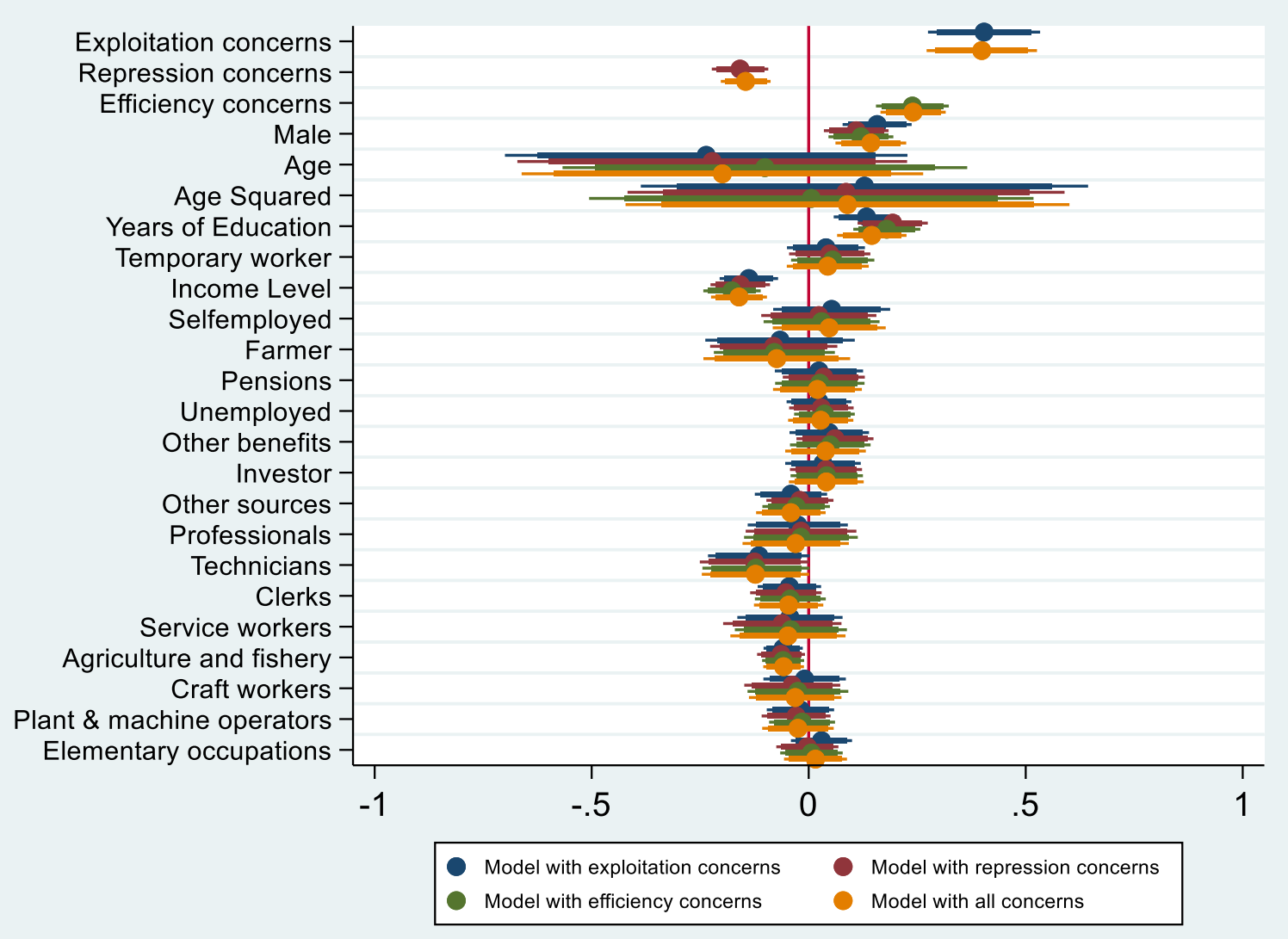


A4.6. Rerunning analysis on whole population (i.e. not restricted to left-wing respondents) 
Figure A4.6.1. Ideological dimensions and support for UBI in whole population with no restrictions to left wing respondents

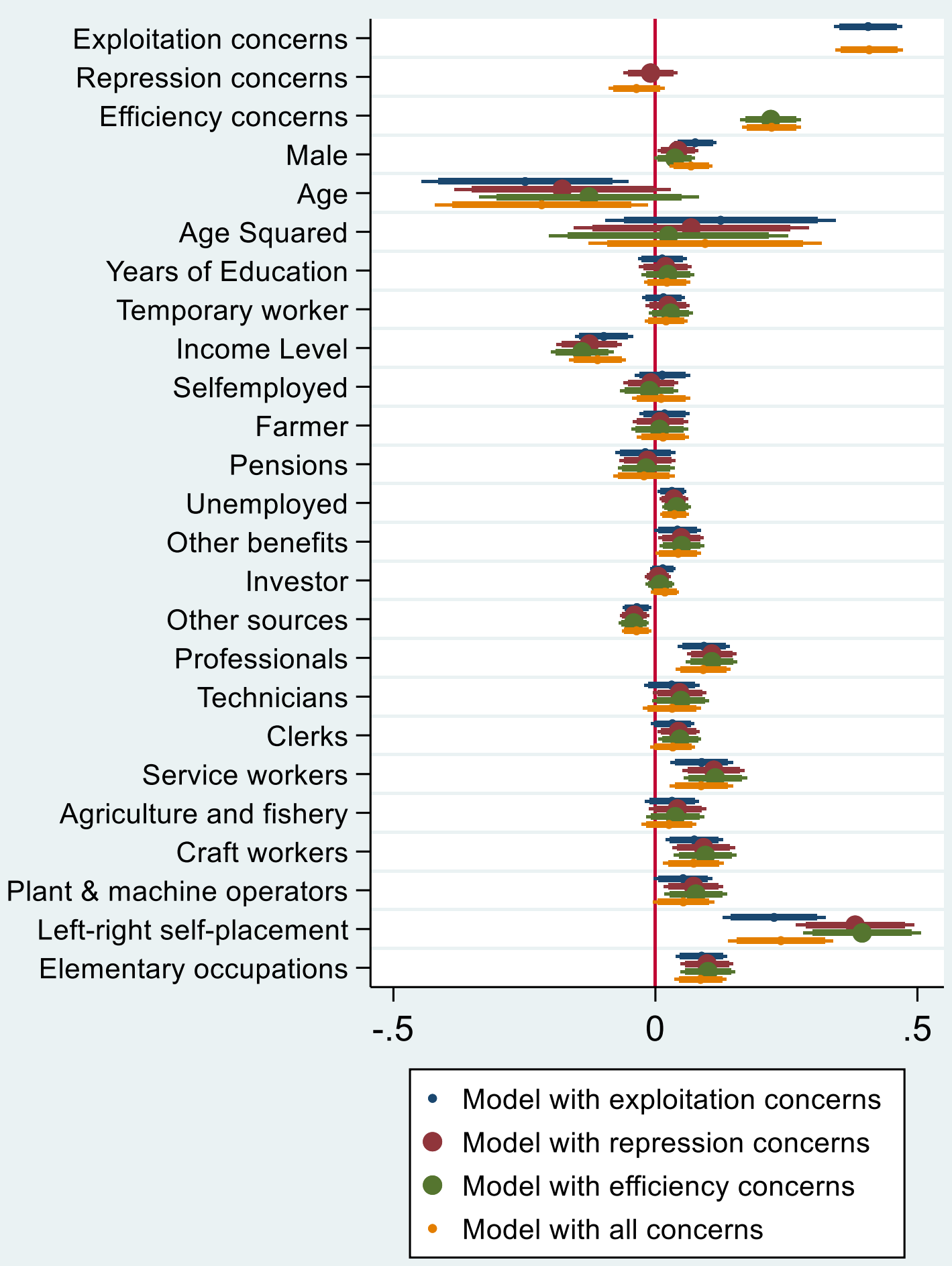


Figure A4.6.2. Ideological dimensions and support for UBI in whole population with no restrictions to left wing respondents and controlling for left selfplacement

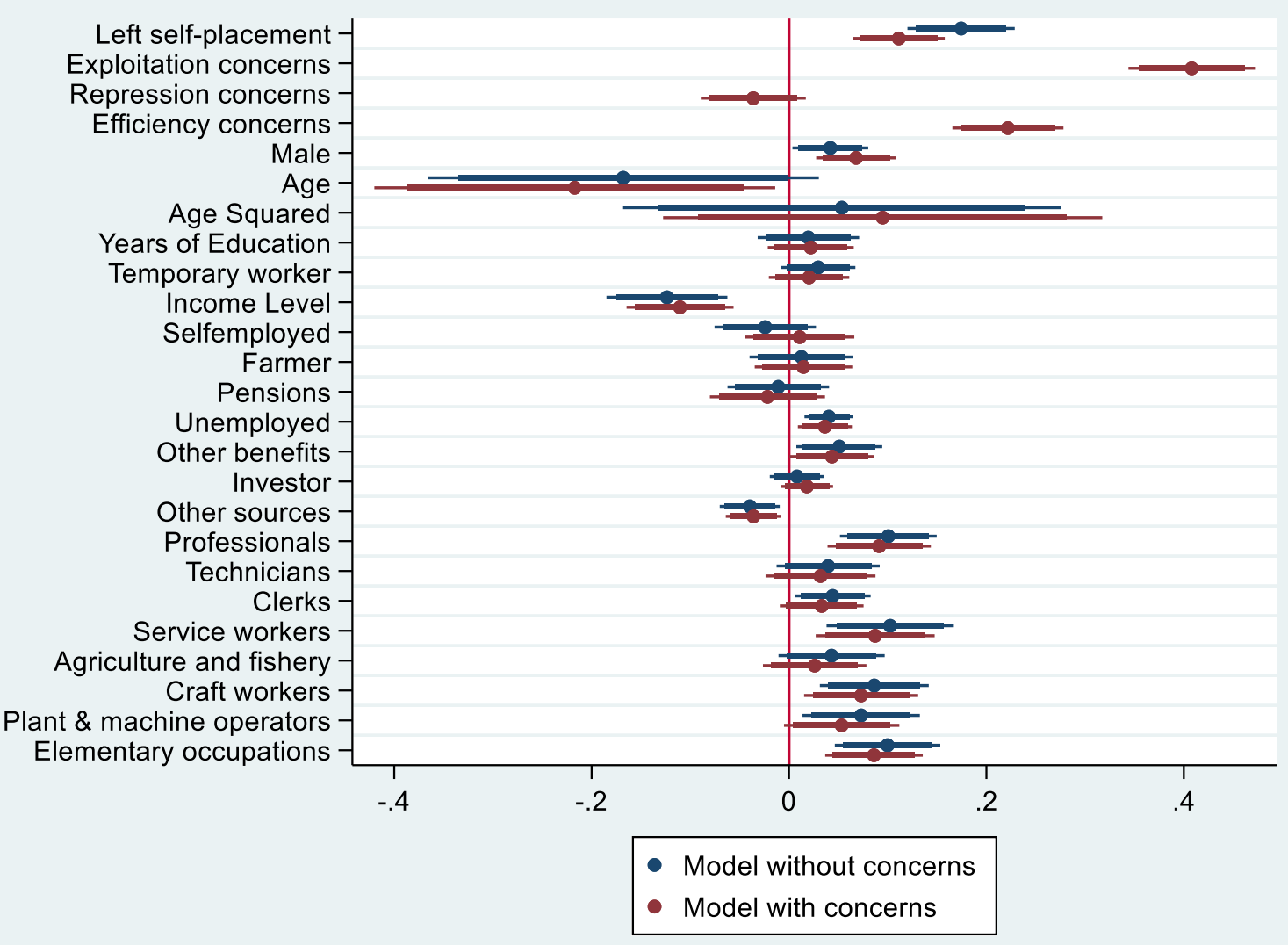

